
YIl 15
Güz 2017
Sayı 23
Ss. $183-220$

Geliş Tarihi: 15.08.2017

Kabul Tarihi: 26.09.2017

\title{
Çok Partili Sisteme Geçişin Sancılı Kesitlerinden Biri: 1947 Yılı Bütçe Görüşmeleri
}

\author{
Gürhan KINALI*
}

\begin{abstract}
$\ddot{O} z$
Uzun yıllar tek partili sistemle yönetilen Türkiye'de uluslararası ortamın da etkisiyle çok partili rejime geçme imkânı doğdu. Savaş dönemi koşullarının körüklediği iktisadi sorunlar yeni bir oluşumun toplumsal taban bulma konusunda zorluk çekmeyeceğini gösteriyordu. CHP içerisinde 1945 yılı ortalarına değin ılımlı ve çekingen bir görüntü sergileyen muhalifler, DP'nin kurulmaslyla çetin bir mücadeleye koyuldu. Ancak çok partili sistemin tecrübesiz tarafları birbirlerine karşı dengeyi sağlamakta oldukça zorlandl. Bu durum DP'nin katıldiğı ilk bütçe görüşmesi olan 1947 yll bütçe görüşmelerine de yansıdl. 7 Eylül Kararları ve devletçilik uygulamalarının temel eleştiri konusu olduğu görüşmelere "Psikopat Olayl" damga vurdu. Meclisi terk eden Demokratların boykotu, partili Cumhurbaşkanı'nın partiler üstü girişimleri ve bunun yansıması olan "26 Aralık Tebliği”" ile aşıld . Çalışmada DP muhalefetindeki bu ilk bütçe görüşmeleri tarafların iktisadi ve mali anlayışları ekseninde politik izdüşümleriyle birlikte incelenmiştir.
\end{abstract}

Anahtar Kelimeler: Psikopat Olayl, 26 Aralık Tebliği, Adnan Menderes, Recep Peker, İsmet İnönü

\section{One of the Painful Sections of Transition to a Multi-Party System: The 1947 Budget Negotiations}

\begin{abstract}
Having been ruled by a single party regime for long years, Turkey found a chance to step into a multi-party regime with the effect of the internationalized scene. Financial problems which were fuelled by war period conditions were showing that a new formation would have no
\end{abstract}

* Gürhan KINALI, Okutman Dr., Kırklareli Üniversitesi, Atatürk İlkeleri ve İnkılâp Tarihi Bölümü, Kayalı Kampüsü Kırklareli, gurhankinali@yahoo.com 
difficulties in finding a social ground. Opponents, who were showing a moderate and timid image within CHP until the middle of 1945, faced an uphill struggle with the establishment of DP. However, inexperienced sides of multi-party regime struggled to find the balance against each other. This situation was reflected in the budget negotiations of 1947, which was the first budget negotiation DP joined. "Psychopath Event" marked the negotiations whose main points of criticism were the "Regulations of September, 7" and Statism practices. The boycott of democrats leaving the parliament was overcome with the supra-party initiatives of the partymember President of the Republic and "the Declaration of December, 26" which was a reflection of this. In the study, these first budget negotiations in DP opposition were investigated from the financial and economical understandings of the sides together with their political projections.

Keywords: Psychopath Event, the Declaration of 26 December, Adnan Menderes, Recep Peker, Ismet Inonu 


\section{Giriş}

İkinci Dünya Savaşı’nın sonlarına doğru “Milli Şef” ünvanı anlamını yitirmeye başlamış, tek partiye dayanan rejimlerin uluslararası ortamın da etkisiyle kendilerini gözden geçireceği bir dönem başlamıştı. 1939 Ocak’ında Cumhurbaşkanı İsmet İnönü'nün talebiyle Başbakanlıktan istifa eden Celal Bayar uzun bir sessizlikten sonra bu dönemde sahneye çıktı. ${ }^{1} 1944$ yılı bütçe görüşmelerinde söz alan Bayar Varlık Vergisi'nin yol açtı̆̆ koydu. Sorularına tatmin edici cevap alamadığı gerekçesiyle bütçeye ret oyu kullandı. Bu sıra dışı gelişme hükümete güvensizlik oyu olarak algılandı. 1945 Ocak'ında Şirketi Hayriye'nin devletçe alınmasına yönelik TBMM görüşmeleri tartışmalı geçmiş, yasaya yedi ret oyu kullanılmıştı. ${ }^{2}$

$\mathrm{Bu}$ oylar tek parti iktidarını hedef alan bireysel hareketlerdi. CHP içinde örgütlü bir muhalefetin varlığı ancak 1945 yılı Mayıs-Haziran aylarında kendini hissettirdi. 1945 Mayıs'ında yapılan 1945 yılı yedi aylık bütçe görüşmeleri Şükrü Saraçoğlu Hükümeti'ne zor anlar yaşattı. Görüşmeler neticesinde Emin Sazak ve altı ay sonra Demokrat Parti'yi kuracak Celal Bayar, Adnan Menderes, Refik Koraltan ve Fuat Köprülü bütçeye ret oyu kullandı. Haziran ayı da oldukça hareketli geçti. Yedi aylık bütçeyi takiben Çiftçiyi Topraklandırma Kanunu'na gösterilen direnç ve Bayar, Menderes, Koraltan ve Köprülü imzasıyla verilen demokrasi taleplerini dillendiren Dörtlü Takrir tek parti hükümetlerinin alışkın olmadığg durumlardı.

Benzer bir durum 1946 yılı bütçesi görüşmelerinde de yaşandı. Tek partili bir ortamda hükümeti denetleme görevini üstlenmesi beklenen Müstakil Grup mensupları bütçe çalışmalarını takdir etmekle yetinmişlerdi. Ancak iktisadi işlerin her geçen gün kötüye gittiğini belirten Hikmet Bayur, hükümeti denetleme mekanizmasının iyi işlemediğini öne sürdü. Daha da ileri giderek "Bu Hükümetin ekonomik alandaki tutuşunu beğenmiyorum. Onun yerine bu işleri daha iyi yapacak bir Hükümetin gelmesini istiyorum" dedi. ${ }^{3}$

Bayur'un sözlerinin yarattığı etki bütçe görüşmelerini ekonomi düzleminden çıkarmış, siyasi denetim ve seçim sistemi konularına odaklanılmıştı. Henüz kurulmakta olan DP'nin yer almadığı 1946 yılı bütçe görüşmelerinde yaşanan tartışmalar, örgütlü bir muhalefetin bütçe görüşmelerindeki etkinliğine 1şık tutmuş, gelecekte DP'nin de yer alacağ́ görüşmelerin çetin geçeğini göstermişti.

Dörtlü Takrir reddedildikten sonra Vatan gazetesine açıklamalarda bulunan Menderes ve Köprülü, partiden çıkarılmışlardı. Buna tepki gösteren Koraltan da ihraç edildi. Gelişmelere kayıtsız kalmayan Bayar, yeni parti kurulmasına yönelik çalışmaları yönlendirmeye başladı. Dünya genelinde demokrasi cephesinin güç ka-

\footnotetext{
1 İsmet İnönü, Defterler 1919-1973, Haz. Ahmet Demirel, İstanbul, Yap1 Kredi Yayınlar1, 2016, s.196.

2 Cemil Koçak, "Siyasal Tarih (1923-1950)", Yakınçağ Türkiye Tarihi 1908-1980, C.I, Haz. Sina Akşin, İstanbul, Milliyet Yayınları, [t.y.], s.173-175.

3 T.B.M.M. Tutanak Dergisi, Dönem:VII, Cilt:20, B:12, 17.12.1945, s.120.
} 
zandığı bir süreç yaşanıyordu. Cumhurbaşkanı İsmet İnönü bu süreçte çok partili siyasal düzene geçişi destekleyen konuşmalarıyla Türkiye'nin çağa ayak uydurması gerektiğine işaret ediyordu. İnönü'nün bu tavrı tek parti içinde hareket imkânı kalmayan muhaliflere cesaret verdi. Neticede Bayar, Menderes, Koraltan ve Köprülü 7 Ocak 1946'da Demokrat Parti'yi kurmuş, böylece çok partili parlamenter rejimin üçüncü denemesi başlamıştı.

Teşkilatlanma sürecindeki DP 1947'deki genel seçimlerin erkene alınması üzerine ciddi bir muhalefet örneği sergilemiști. DP, seçim kararına ilişkin bildirisinde muhalefete yayılma zamanı tanınmadığını belirtmiş, demokrasiyle bağdaşmayan kanunlar kaldırılmadığı sürece seçim güvenliğinin sağlanamayacağını savunmuştu. ${ }^{4} \mathrm{DP}$, usulsüzlük iddialarıyla adından söz ettiren 21 Temmuz 1946 seçimlerinde 54 milletvekili çıkardı. CHP, 403 milletvekili ile hâkimiyetini korudu. ${ }^{5}$ Seçim atmosferi, iktidarın sayısal üstünlüğüne rağmen hükümetin rahat bir icra dönemi geçirmeyeceğinin sinyallerini vermişti. Cumhurbaşkanı İnönü böylesi bir ortamda hükümeti kurma görevini çok partili yönetime kuşkuyla bakan Recep Peker'e verdi. ${ }^{6}$ Saraçoğlu Peker değişikliği hükümetin sertlik yanlısı bir anlayışla idare edileceği algısına yol açtı.

DP, CHP'nin siyaset anlayışının yanında iktisat politikalarına da ciddi eleştiriler getirdi. 1940'da İthalatçı Birliklerinin kurulması, 1941'de kliring, özel takas ve serbest dövizli ödeme sistemlerini barındıran Dış Ticaret Kararnamesi'nin kabul edilmesi ve ihracata prim uygulaması getirilmesi dış ticaretin devlet denetimine girmesine yol açmıştı. ${ }^{7}$ Savaş ekonomisine özgü bu uygulamaların yumuşatılması bekleniyordu. Müdahaleci uygulamalara karşı olan DP, programında iktisat anlayışını şöyle duyurmuştu: "Paramızın klymetini, serbest piyasa döviz kıymetleriyle, memleketimizin iktisadi ve mali durumuna en uygun şekilde, ayarlamak ve bu esas üzerinde tam bir istikrar sağlamak zarureti karşısındayız."

1946 seçimlerinden sonra kurulan Peker Hükümeti programında ticareti kısıtlayan düzenlemelerin kaldırılması ve serbest ticaret sistemine geçiş öncelikli iktisadi hedefler arasında gösterilmişti. ${ }^{9}$ Bu söylem DP'nin ekonomik anlayışıyla da örtüşüyordu. CHP Meclis Grubu, iç piyasada paranın fazla değerlendiği ve dış ticaret fazlası

4 Murat Karataş, “Cumhuriyet Halk Partisi’nin Siyasal İktidar Anlayışı (1946-1950)”, Uluslararası Sosyal Araştırmalar Dergisi, Cilt: 7, Sayı: 29, 2014, s.506.

5 Mahmut Goloğlu,Türkiye Cumhuriyeti Tarihi-IV 1946-1950 Demokrasiye Geçiş, İstanbul, Türkiye İş Bankası Kültür Yayınları, 2013, s.71-72.

6 Rıdvan Akın, Türk Siyasâl Tarihi 1908-1920, İstanbul, XII Levha Yayınları, 2010, s.342., Ahmet Hamdi Başar'a göre İnönü, “demokratik rejime inanmayan” Peker'i, CHP içinde muhalefete tahammül edemeyen grup ağır bastığından gönülsüz de olsa Başbakan yapmıştı. Bkz.; Ahmet Hamdi Başar, Ahmet Hamdi Başar'ın Hatıraları: "Yine Hayal Âleminde Uçuyorum...”, C.II, Haz. Murat Koraltürk, İstanbul, İstanbul Bilgi Üniversitesi Yayınları, 2007, s.167.

7 Yahya S. Tezel, Cumhuriyet Döneminin İktisadi Tarihi, 5.bs., İstanbul, Tarih Vakfı Yurt Yayınları, 2002, s.182-183.

8 Tarık Zafer Tunaya, Türkiye'de Siyasi Partiler 1859-1952, 3.bs., İstanbul, Arba Yayınları, 1995, s.669.

9 İsmail Arar, Hükümet Programları 1920-1965, İstanbul, Burçak Yayınevi, 1968, s.172. 
stoklarının belirleyici olduğu bir dış ticaret ortamında devalüasyon kararı aldı. 7 Eylül 1946'da alınan bu kararla dövize prim uygulaması sonlanmış, 130 kuruş olan bir doların alış fiyatı 280 kuruş, satışı ise 282,80 kuruş olarak tespit edilmişti. ${ }^{10}$ DP programında paranın uygun şekilde ayarlanması gerekliliğine vurgu yapılsa da devalüasyon kararına büyük tepki gösterilmişti. Partinin bu tavrı katıldıkları ilk bütçe görüşmesine de yansid1.

1947 yılı bütçesi görüşmelerinde devletçilik uygulamaları ve 7 Eylül Kararları iktisadi tartışmaların odak noktasını oluşturdu. Görüşmelerin henüz başında patlak veren Psikopat Olayı siyasal bir krize sebep oldu. Çalışmada Demokrat Parti'nin muhalefette bulunduğu 1946-1950 döneminde katıldığ1 ilk bütçe görüşmeleri olan 1947 yılı bütçesinin odak noktası aktarılmış, tarafların ekonomik ve mali anlayışları siyasi yansımaları nezdinde ele alınmıştır.

\section{Yılı Bütçe Tasarısı}

Bütçeler, hükümetlerin belirli bir süre için tasarladığı zaman diliminde gelir ve gider hesaplarını ortaya koyar. Hükümetin izleyeceği iç ve dış politika ile iktisadi ve idari işler konusunda bilgiler içerir. Dolayısıyla görüşmeler esnasında ekonomik mevzuların dışına çıkılarak hükümetin politik anlayışı da masaya yatırılır.

1947 y1lı bütçesi görüşmeleri 18 Aralık 1946'da başlamış, ilk sözü Başbakan Recep Peker almıştı. Peker, açılış niteliğindeki kısa konuşmasında politik bir tavır sergilemiş, sundukları bütçenin rakamları içinde gömülü bulunan esasların en önemlisinin, yurdun bağımsızlığını emniyet altında tutma olduğunu belirtmişti. İç politikadaki telkinlere de değinen Peker, "bilhassa günlük politika maksatlart ile yapılmış ve yayılmış olan telkinlerin neticesinde her hangi bir köşeden çıkması ihtimali olan bozgunculuk hareketini de kati surette önlemek ve yine istiklâl meselesindeki dikkat ve taassup derecesindeki bir dikkatle ve uyanıklıkla iç huzuru, iç emniyeti mutlaka masun tutmak en mühim esastır" diyerek, iç emniyetin Hükümetin ana gayeleri arasında bulunduğunu vurgulamışt1.

Huzuru bozacak girişimlerin doğuracağı kanunsuz hareketlerin kanun gücü ile önleneceğini belirten Peker, bir anlamda DP milletvekillerine gözdağ́ vermişti. Ayr1ca Meclisin bütçe incelemesini tam bağımsızlık duygusuyla yaptığına temas ederek, bütçe görüşmelerinin partisel hesapların dışında tutulması gerektiğini savunmuştu. ${ }^{11}$

1947 Y1lı Bütçe Kanunu Tasarısı'nda giderler 1 milyar 136 milyon lira, gelirler ise 1 milyar 21 milyon lira olarak belirlenmiş, bütçedeki 115 milyon liralık açığın iç borçlanmaya başvurularak giderilmesi öngörülmüştü. Peker'den sonra hükümet adına

10 Serkan Tuna, “Cumhuriyet Döneminin İlk Devalüasyonu 7 Eylül 1946,” Akdeniz İİBF Dergisi, Cilt:7, Sayı:13, Mayıs 2007, s.89-97., Böylece fiyat ve miktar sınırlamaları kaldırılacak olan ithalattaki artışı sınırlı tutmak ve ihracatı arttırmak hedeflenmişti. Bkz.; Yakup Kepenek, Nurhan Yentürk, Türkiye Ekonomisi, 19.bs., İstanbul, Remzi Kitabevi, 2007, s.121.

11 T.B.M.M. Tutanak Dergisi, Dönem:VIII, Cilt:3, B:18, 18.12.1946, s.3-5. 
bütçeyi Maliye Bakanı Halit Nazmi Keşmir değerlendirdi. Keşmir, bu bütçenin de 1946 yılı gibi geçiş bütçesi olduğunu belirtti. Buna gerekçe olarak İkinci Dünya SavaŞ1 sonlanmasına karşın milli savunma harcamalarına ayrılan ödeneğin bütçe içindeki payını korumasını gösterdi. ${ }^{12}$

Aylıklar \%35, daire hizmetleri \%26, borçlar \%19,4 ile 1947 bütçesinin en yüklü üç gider ödeneğini oluşturmuştu. Bütçe komisyonu 1946 bütçesine göre 127 milyon lira fazla gelir tespit etmişti. Bu durumda vergi gelirlerinde sağlanan artışlar etkiliydi. Gümrük vergisi ve resimleri, ithalat ve üretim muamele vergileri ile hizmet sektöründen alınan vergiler artış göstermişti. Maliye Bakanlığı, gelir vergilerinin baştan düzenlenerek tüketim vergileri oranlarının aşamalı düşürülmesini amaçlıyordu. Bu kapsamda bütçe genelinde gelir artışı sağlanmasına karşın tüketim ve tekel vergilerinde azalma görülmüştü. Örneğin şeker tüketim resminde indirim yapılmış, bazı tüketim vergileri kaldırılmış, kahve tekelden çıkarılmış, çay resmi yarıya düşürülmüştü. ${ }^{13}$

115 milyon liralık bütçe açığını iç borçlanmayla gidermeyi tasarlayan Hükümet, ekonomik kalkınmayı gerçekleştirecek yatırımlara odaklanarak borçları uzun vadeli olarak yapılandırmayı hedeflemişti. Maliye Bakanı Keşmir, bütçenin \% 18'ine tekabül eden borç tutarının yüksek olmadığı kanaatindeydi. Savını kuvvetlendirmek isteyen Keşmir, İkinci Dünya Savaşı'na dâhil olmayan İsviçre ve İsveç bütçeleriyle karşılaştırmalarda bulundu. Buna göre 30 Eylül 1946 itibariyle borç toplamı 1 milyar 653 milyon liradır. Bunun 891 milyonu uzun, 762 milyonu kısa vadelidir. Kisa vadeli borçların bütünü, uzun vadelilerin ise 332 milyonu iç borçlanmadır. Bu rakamlar ile borç tablosunu ortaya koyan Keşmir, borç toplamının yıllık bütçenin bir buçuk katı olduğunu söyledi. 1945 yılı itibariyle aynı oranın İsviçre'de yıllık bütçenin beş, İsveç’te ise üç buçuk katına denk geldiğini belirtti. İhracatın arttığını, altın ve döviz rezervlerinin varlığını koruduğunu sözlerine ekleyen Maliye Bakanı, genel ekonomik durumun iyileştiğini öne sürdü. ${ }^{14}$

Bütçe tasarısını değerlendiren Nadir Nadi, Peker Hükümetinin Türk parasının kıymetini yeni dünya şartlarına uydurmak, dış ticareti geliştirmek ve genel kalkınmayı sağlamak amacıyla aldığını belirttiği 7 Eylül Kararlarının yeni bütçenin içinde toplandığını savundu. Bütçedeki açığı şöyle yorumladı: "Mademki paramız yeni şartlara uydurulmak istenmiştir ve mademki aylıklara büyük ölçüde zamlar yapılmıştır, böyle bir fark elbette olacaktı. Bütçede göze çarpan yüz küsur milyonluk açı̆̆ın da kendi başına mühim bir manasl yoktur." 15

12 Tutanak Dergisi, a.g.e., s.5-6.

13 Tutanak Dergisi, a.g.e., s.7-8.

14 Tutanak Dergisi, a.g.e., s.8-9.

15 Nadir Nadi, "Yeni Bütçe", Cumhuriyet, 03 Ekim 1946. 


\section{Demokrat Parti’nin Bütçe Değerlendirmesi}

DP adına bütçe değerlendirmesini Kütahya milletvekili Adnan Menderes yaptı. Menderes, hazırlanan yazılı konuşma metnini okumak suretiyle partisinin görüşlerini açıkladı. Menderes konuşmasının başında Başbakan Recep Peker'i, “şiddetli bir lisan kullanarak" bütçe üzerinde yapılacak tenkitleri engellemek ve iç emniyeti bahane ederek muhalefeti "ürkütmek" ile suçladı. Peker'in karışıklıkların bastırılacağına yönelik açıklamalarına şöyle tepki verdi:

"Demokrat Parti kendisini, bu gibi imaların asla tesiri kalmayacak să̆lam bir durumda görüyor. Çünkü Demokrat Parti kuruluşundan bu güne kadar kanuni yollarla ve kanun vasitasiyla mücadeleyi kendisine en mukaddes bir şiar edinmiştir. Bundan böyle de sonuna kadar bu yolda azim ile irkilmeden devam edecektir. Sayın Başbakanın bu nevi şiddetli sözlerinin, Bütçenin müzakeresine takaddüm eden dakikalarda söylenmiş olmasının ve bütçe müzakereleriyle hiçbir ilgisi bulunmamasının manası üzerine ayrıca dikkati çekmek yerinde olur." 16

Menderes, bu sözlerinin ardından DP'nin 1947 yılı bütçesi hakkındaki görüşlerini açıklayan uzun bir konuşma gerçekleştirdi. Yıllık milli gelir ve bu gelirin sektörlere göre dağılımının belirlenmesinin vergilerin meslek gruplarına göre adil düzenlenmesine katkı sağlayacağını söyledi. ${ }^{17}$ Özel idareler, belediyeler ve köy bütçelerine ödenen vergi ve resimlerin miktarı ile Kamu İktisadi Teşekküllerinin yaptıkları masraf ve işletme prensiplerinin uygulama sonuçlarının Meclisçe bilinmesi gerektiğini belirtti. Şekle ait olduğunu söylediği bu eksiklerin bütçenin şeffaflığına gölge düşürdüğünü savundu. ${ }^{18}$

Menderes Milli Korunma, Türk Parası Kıymetini Koruma ve Merkez Bankası gibi bazı kanunların uygulama yetkisinin Meclisten alınarak yürütme erkine verilmiş olmasını bütçenin takibini zorlaştıran etkenler arasında saymıştı. Ayrıca dış ticaret ve döviz alım satım işlemlerinden sağlandığını belirttiği 135 ton altının bütçede yer almadığına ve döviz bütçesinin de bilinmediğine bahisle bu hallerin de Meclisin denetleme görevini zorlaştırdığını öne sürmüştü. ${ }^{19}$

DP'lilere göre Meclisçe kabul edilen bütçe ile bütçe kesin hesaplarının kıyaslaması bütçenin samimiyetine 1 şı tutuyordu. Menderes, her sene denk olarak sunulan bütçelerin sene sonlarında büyük açıklarla kapandığını, 1939-1946 yılları arasında

16 Tutanak Dergisi, a.g.e., s.15-16.

17 Devletin yüksek görevlilerinden biri olarak görüşmeleri yakından izleyen Şevket Süreyya Aydemir, vergilerin milli gelirdeki meslek gruplarına göre tespiti esasının "adaletli bir görüş" olduğuna dikkat çekmiş, Menderes'in bunu savunmasını "heyecan verici” bulmuştu. Bkz.; Şevket Süreyya Aydemir, Menderes'in Dramı? (1899-1960), 15.bs., İstanbul, Remzi Kitabevi, 2014, s.170.

18 Tutanak Dergisi, a.g.e., s.16.

19 Tutanak Dergisi, a.g.e., s.17. 
toplamda 1 milyar 290 milyon liralık borç yükü ortaya çıktığını, 1947 yılı bütçesinin de bunlardan biri olacağını iddia etti. Bunu kanıtlamak için Milli Savunma Bakanlığı bütçesini örnek gösterdi. Milli Savunma Bakanı Cemil Cahit Toydemir'in, 7 Eylül Kararlarının sebep olduğu fiyat yükselişlerinin, savunma giderlerine bütçede hesaplanmayan 8 milyon liralık ek yük getirdiği şeklindeki açıklamasını hatırlattı. Ayrıca Milli Savunma Bakanlığının, Toprak Mahsullerine olan 51 milyon liralık borcunun bütçede ödenek olarak yer almadığını söyledi. ${ }^{20}$

Açıklamalarını sürdüren Menderes, sıkıyönetim altı ay daha uzatılmasına rağmen barış dönemi bütçesi olan 1938 yılına göre milli savunmaya daha az ödenek ayrıldığını, bu bağlamda savaş tehlikesinin sıkıyönetimi uzatma bahanesi olarak kullanıldığını savundu. 1947 yılı bütçesi 1938 yılına kıyasla \% 357 artmıştı. Milli Savunma Bakanlığ 1 bütçesi de buna eşdeğer bir seyir izleyerek \% 350 artmıştı. Menderes'e göre bu rakamlar, mali sıkıntıların savunma ihtiyaçlarından kaynaklanmadığını gösteriyordu. ${ }^{21}$

Hükümet, bütçe açığını iç borçlanma ile kapatmayı tasarlamıştı. Borçlanmanın yapı, sermaye ve kredilere ayrılacağı, karşılığının gelecek yıllarda alınacağ söylenmişti. Menderes, bu söylemlerin bütçe açığına karşı mazeret olarak ileri sürüldüğü, ayrıca 7 Eylül Kararlarının etkisi ile meydana gelen fiyat artışlarının, bütçedeki açığıı belirtilen tutardan fazla çıkmasına yol açacağı görüşündeydi. ${ }^{22}$

Tasarruf konusuna gereken önemin verilmediğini söyleyen Menderes, hükümetin bütçe gerekçesinde yer bulan gider kalemlerinde tasarruf sağlandığ rağmen indirilen rakamların çok sınırlı olduğunu ifade etti. Hizmet kadrosunda meydana gelen artışlar neticesinde maaş, hizmet, büro ve idare masraflarının 189 milyon lirayı aştığını belirtti. ${ }^{23}$

Devlet borçları 1939'dan 1946 Ekim'ine kadar \% 375 artarak 1 milyar 847 milyon liraya ulaşmıştı. Devlet borçlarının \% 46'sını oluşturan dalgalı borçların azaltılmaS1 çabaları komisyon raporunda yer almıştı. ${ }^{24}$ Alınan tedbirlerle dalgalı borçların 762 milyon liradan 322 milyon liraya indirilmesi planlanmış, 322 milyon liranın 137'sinin acil ödenme zorunluluğu görülmemişti. Menderes, geriye kalan ödenmesi zorunlu miktarın, nasıl kapatılacağı konusunda açıklama yapılmadığını söyledi. Ona göre bu

20 A.e.

21 Tutanak Dergisi, a.g.e., s.17-18.

22 Tutanak Dergisi, a.g.e., s.18.

23 Tutanak Dergisi, a.g.e., s.19.

24 Bütçe Komisyonu bu konuda şu tedbirleri almıştı: “1) 4060 sayılı kanunla çıkarılan ve kısa vadeli dalgalı borçlarda sayılan bonuların uzun vadeliye çevrilmesi 2) Merkez Bankasındaki altın ve dövizlere yeni kıymet konulmasından tahassül eden 260 milyon liralık faydanın 234 milyonu ile altın ve döviz karşılığı olarak Merkez Bankasınca Maliye Bakanlığına yapılmış olan avansın kapatılarak mütebakisinin diğer dalgalı borçlara tahsisi.", Bkz.; A.e. 
tedbirler gerçek bir ödeme değildi. Çünkü ilki bono vadelerinin uzatılmasından diğeri ise altın ve dövizlere yeni değer belirlenmesinden meydana gelmişti. ${ }^{25}$

Menderes konuşmasını yaparken CHP'li Meclis Başkanı Kazım Karabekir'in uyarısıyla karşılaştı. İç tüzük gereğince yazılı nutuklar 15 dakikadan fazla sürmemeliydi. Karabekir 25 dakika olduğu halde konuşmasının üçte birini tamamlamayan Menderes'e bu durumu hatırlatarak, konuşmasına yazılı metin olmadan devam etmesini istedi. Bununla birlikte Halk Partisi milletvekilleri Menderes'in okumayı sürdürmesi yönünde tavır koydular. Asım Us'a göre bunun sebebi muhalefetin görüşleri dinlenmek istenmiyor şeklinde bir algıya yol açmamaktı. ${ }^{26}$

Menderes konuşmasına devamla Demokrat Parti'nin vergiler konusundaki anlayışına değindi. Buna göre bütçedeki gelirlerin ağırlık merkezini vasıtasız vergiler oluşturmalıydı. Vasıtalı vergilerden özellikle geçim şartlarını zorlaştıran muamele ve tüketim vergilerinden kaçınılmalı, gümrük tarifeleri zaruri gıda ve ihtiyaç maddeleri ile üretim araçlarını dışarıda bırakacak şekilde oluşturulmalıydı ${ }^{27}$

Gelir bütçesinin \% 56'sını oluşturan vasıtalı vergiler giderek artma eğilimi göstermişti. 349,5 milyon liralık vasıtasız vergilerin 112,5 milyon lirası ticari ve sınai teşebbüs sahiplerinden, 237,5 milyon lirası hizmet sahiplerinden alınacaktı. Menderes, hizmet sektöründen alınacak verginin, bütün ticaret ve sanayi işletmelerinden alınacak vergi miktarının iki katından fazla olmasını, vergi adaletsizliğinin kanıtı olarak sundu. ${ }^{28}$

Hizmet sektörü hariç, kazanç vergisi geliri savaştan önce 26 milyon lira iken, 110 milyon liraya çıkmıştı. Buna karşın vasıtalı vergiler sınıfında yer alan imalat muamele vergisi 10 milyon liradan 110 milyon liraya yükselmişti. Menderes, iki verginin farklı oranlarda değişerek vasıtalı vergilerin daha hızlı artış göstermesine temasla kazanç vergisi sisteminin sağlıklı işlemediğini öne sürdü. Ona göre hükümet, fiyat yükselişlerini önlemek için muamele vergisinde azaltmalar yapmadığ 1 gibi yararlanması kolay olduğu için daha da yükseltme yoluna gitmişti. ${ }^{29}$

Menderes, Peker kabinesinin hükümet programında yer alan; sanayileşme hareketine yeni şart ve imkânlardan faydalanılarak hızla devam edileceği, yeraltı zenginliklerini değerlendirme konusundaki çalışmaların arttırılacağı, büyük enerji santralleri inşaat programının biran evvel gerçekleştirilmeye çalışılacağı, üreticiye yeterli miktarda araç temin edileceği, vagondan lokomotife kadar nakil vasıtalarının yurt içinde yapma çabalarının arttırılacağı, liman ve iskelelerin modern bir şekilde

25 Tutanak Dergisi, a.g.e., s.19-20.

26 Asım Us, Hatıra Notları, Haz. İsmail Dervişoğlu, İstanbul, Kitabevi Yayınları, 2012, s.624.

27 Tutanak Dergisi, a.g.e., s.20.

28 A.e.

29 Tutanak Dergisi, a.g.e., s.20-21. 
cihazlandırılacağı, deniz endüstrisinin gemi yapacak hale getirileceği, tütün ve kredi maritim bankalarının kurulacağı, büyük su işlerine devam edileceği ve ilk on beş yıl içinde 20 bin kilometre yol yapılacağı şeklindeki mali politikaya ilişkin vaatlerin, bu bütçe imkânlarıyla mümkün olamayacağını savundu. Bu kapsamda hükümet programında bahsi geçen demiryolu bakımı için 1 milyar liraya yakın, sulama ve kurutma için 1 milyar 800 milyon lira ve 15 yılda yapılması düşünülen 20 bin kilometre yolun yıllık maliyeti için ise 200 milyon liraya ihtiyaç duyulacağını söyledi. ${ }^{30}$

Menderes'e göre hükümet, her alanda kalkınmadan bahsetse de dış ticaret hacminin daralması gerilemenin kanıtıydı 1929 yılında dış ticaret hacmi 100 kabul edildiğinde 1946 yılının ilk on ayındaki dış ticaret hacmi 44'tü. Dolayısıyla iktisadi gerilemenin sebebi izlenen hatalı mali politikalardı. Bu politikalar geçimi zorlaştıran ve gelecekteki yükü arttıracak etkiler yapmaktaydı. Menderes konuşmasına devamla bütçeye uygun olmayan geniş kadrolu teşkilatların, bütçe olanaklarının verimsiz sahalara nakledilmesinin, katma bütçe açıklarının ve KİT'lerin sebep olduğu yüklerin milli ekonomiye 2 milyarlık maliyet getirdiğini iddia etti. Ayrıca, yılsonunda tahmini bütçe açığının 300 milyon lira olacağını, bu açığın yeni borçlanmalar ve emisyonla sonuçlanacağını ileri sürdü. ${ }^{31}$

Menderes, partisi adına yaptığı bütçe konuşmasında hükümete yönelik esaslı eleştirilerde bulunmuştu. Mevcut ekonomik durumun sorumlusu olarak savaş yıllarının olağanüstü koşullarını "bahane eden” hükümeti göstermişti. Eleştiri dozunu arttıran Menderes, işbaşındaki yönetim anlayışının ekonomik sorunlara derman olamayacağını, yeni bir zihniyete ihtiyaç duyulduğunu şöyle ifade etti:

"Bu istıraplı akışa dur diyebilmek işleri bu hale getiren ve gösterişe kolaya kaçan görüş ve zihniyetten beklenemez. Bu müşahedemiz bir parti şahıs görüşü değil memlekette son yüz yll içinde görülen siyasi gelişme ve kaynaşmalarda ifadesini bulmuş bir hakikattir. Bugün müspet bir politika ve memleket görüşü ile kuvvetlerini ele alarak bunlara mutlaka iktisadi bünyenin kuvvetlenmesine tevcih ederek bütün müşülleri birer birer yapmak mümkündür. Bu ise, içinde milletin güvenini duyan yeni bir şuur ve hamlenin eseri olabilir." 32

Menderes'in bütçe konuşmasını değerlendiren Metin Toker, "ince, esprili ve iğneli - hatta çuvaldızlı" bir konuşma hazırlandığını ve bunun maharetle okunduğunu savundu. Toker, iktidarın tahrik edilmek istendiği kanaatindeydi. Bu kanaatini şöyle ortaya koydu: "Zaman zaman duruyor, gözlükleri çıkarıp alaylı bir şekilde hükümete bakıyor, karşısındakileri sinirlendirmek için her şeyi yapıyordu. Bunda muvaffak da oldu." 33 Şevket Süreyya Aydemir de aynı kanıdayd1. Aydemir, Menderes'in "yapma-

30 Tutanak Dergisi, a.g.e., s.21-22.

31 Tutanak Dergisi, a.g.e., s.21-23.

32 Tutanak Dergisi, a.g.e., s.23.

33 Metin Toker, Tek Partiden Çok Partiye, İstanbul, Milliyet Yayınları, 1970, s.222-223. 
c1k bir tebessüm" ve "alaylı bakışlar" ile otoriter hükümetin temsilcisi Peker'in tahammül edemeyeceği bir "gösteri”" gerçekleştirdiğini aktarmıştı. ${ }^{34}$

\section{"Psikopat Olayı"}

Menderes'in ardından teamül dışı olarak Başbakan söz aldı. Menderes'in tenkitleri kadar konuşması esnasında takındığı tutumun Peker'i kontrolden çıkardığı anlaşılıyordu. Onun hükümet işleri hakkında kötümserlik yaratma zihniyetiyle konuştuğunu düşünen Peker, kendine hâkim olamayarak şöyle karşılık verdi:

"Muhterem arkadaşlarım, Demokrat Parti adına dinlediğiniz Adnan Menderes'in sesinde kötümser ve psikopat bir ruhun mariz karanlıklar içinde. Şanlı bir milletin ve arkada bıraktı̆̆ karanlıklardan azametli, şan ve şerefli bir istikbale gitmek azminde bulunan kudretli bir Devletin hayatını bir boşluk halinde ifade eden ruh haletinin akislerini dinledik. Bu ruh haletine temas ettiğim zaman kendimi derin bir hakikati keşfetmiş vaziyette görüyorum. Demek ki, her şeyi geriye çeken anlaşılmaz hareketler bir ruhtan doğuyor. Vazife başına geldiğimiz günden beri bu kürsüye gelip bizden hesap sormaların istediğimiz zaman her defasında bir usul meselesi çıkararak karşımıza çıkarak konuşmaktan kaçan bu Parti" 35

Bu esnada Demokratlar ayağa kalkarak Başbakan Peker'e bağırmaya başladı. Bayar, "Daha nasıl konuşalım” diyerek karşılık verdi. ${ }^{36}$ Peker'in açıklamaları esnasında önce Menderes için "psikopat bir ruhun ifadesi”" demesi ardından DP için "açık konuşmaktan kaçan parti” betimlemesini yapması tansiyonu yükseltmiş, DP milletvekilleri arasında "çıkalım arkadaşlar” sesleri duyulmaya başlamıştı. Peker'in sözlerini pek anlamayan DP'li Emin Sazak, "Bize pis köpek dedi arkadaşlar. Gidelim. Terkedelim" demişti. ${ }^{37}$

Celal Bayar'ın görüşmelerin terk edilmesine yönelik çağrısıyla DP'liler toplu olarak salonu terk etti. Bazı CHP milletvekilleri kendilerini engellemek istemiş, başarılı olamamıştı. Peker, bu duruma şöyle tepki gösterdi:

"Arkadaşlar, ilk defa kendileri gibi değil, kendilerinin her gün konuştuğundan daha saygıll, daha ihtiyatlı olarak ilk defa konuştuğum zaman sıraları terkettiler. Memlekette temel saydığımız Demokrat fikirleri, çok teessüf ederim bu arkadaşların müdafaa etmesi gibi bir talihsiz vaziyette bulunuyoruz. Herşeyi haksız ve hesapsız söyleyenler mesul bir adamın hakkı belirtmek için yaptı̆̆

34 Şevket Süreyya Aydemir, İkinci Adam 1938-1950, C.II, 11. bs., İstanbul, Remzi Kitabevi, 2011, s.457.

35 Tutanak Dergisi ,a.g.e., s.23.

36 Cumhuriyet, 19 Aralık 1947.

37 Toker, a.g.e, s.223., Başar, a.g.e., s.167. 
tahlili dinlemeğe tahammül edemiyorlar. Hani demokrasi fikirlerin serbestliği ve hani onlar bunu kuracaklardı?" 38

Konuşmasını sürdüren Peker, DP'lileri halkı kışkırtmaya yönelik söylemlerde bulunmakla suçladı. İlk konuşması esnasında böyle bir ortama izin verilmeyeceğini, "memlekette meşru nizamı temin edeceğim" sözüyle ortaya koymuş, Menderes bundan ürkütücü bir mana çıkarmıştı. "Psikopat bir ruh" sözünün arkasında durduğu anlaşılan Peker, şöyle dedi: "Arkadaşlar, bir insanın kendi ruhundaki duygu salimse hükümetin bu sözünü haz verici bir rahatlık unsuru telâkki eder. Fakat kendi ruhu bu söylediklerimi suç telâkki ederse ancak o zaman gocunur, benim sözlerimde ürkütücü bir tesir görebilir." 39

Menderes'in bütçe hakkında yaptığı hesap ve verdiği rakamların \% 90'ının yanlış, geri kalanının da düzeltilmeye muhtaç olduğunu söyleyen Peker, ilgili bakanların bunlar hakkında açıklamalarda bulunacağını belirterek nutkunu tamamladı. ${ }^{40}$

CHP Tunceli Milletvekili Necmeddin Sahir Sılan, Başbakan Peker'in bu oturumdaki konuşmasının olduğu gibi en uzak köylere kadar yayılmasına ilişkin bir takrir vermiş, teklif kabul edilmişti. Ancak bu tatsızlık bazı CHP milletvekillerinin Peker'e cephe almasına yol açmıştı. Örneğin takririn ardından usul hakkında konuşmak üzere söz alan CHP İstanbul milletvekili Hamdullah Suphi Tanrı̈ver, Peker'in, DP sözcüsü Menderes'in haksız olduğu hususlar CHP milletvekilleri tarafindan savunulduktan sonra hükümet adına son değerlendirmeyi yapmasının uygun olacağını söyledi. Peker'in tutumunu şöyle tenkit etti:

"Onun başta müdahalesi ve son derece sinirli olarak müdahalesi ve sözleri arasinda mariz kelimesini, psikopat kelimesini kullanmasl, ifade ediyorum borcumdur, onun haiz olduğu makamın, bilhassa bizzat tatbik ettiği müdafaa ettiği usulün, lüzum gösterdiği büyük esaslar haricindedir... Malî meseleleri iyi anlatabilecek mütehassıslarımız var, onlar konuşsunlar. Recep Peker Hükümet reisi olarak, ilk kürsüye çıktığı zaman fevkalâde mutedil bir lisan kullandı, herkese ümit verdi. Ondan sonra da bütün nutuklarında aynı haleti ruhiyeyi gösterdi. Fakat şimdi böyle bir infiali makamının verdiği büyük nüfuzla burada kullanılmă̆a başlarsa biz ziyanlı bir vaziyete düşeriz." ${ }^{41}$

Tanrı̈ver, takrir sahibi Sılan'ın ve CHP Balıkesir milletvekili Süreyya Örgeevren'in müdahaleleri arasında konuşmasını tamamladıktan sonra Peker yine söz aldı. Tanrı̈̈ver' in değerlendirmesini hatalı bulan Peker, Menderes'e karşı kullandığ 1 sözlerin haklılığını savunmaya şöyle devam etti:

38 Tutanak Dergisi, a.g.e., s.24., Cumhuriyet, 19 Aralık 1946.

39 Tutanak Dergisi, a.g.e., s.24-27.

40 Tutanak Dergisi, a.g.e., s.27.

41 Tutanak Dergisi, a.g.e., s.27-28. 
"Mariz kelimesi Türk âdabında, Türk lügatlerinde, Türk münasebetlerinde hiçbir hakaret ifade etmeyen bir kelimedir. Psikopat, mariz, kötümser, karamsar... bunların ifade ettiği mânaları bir yı̆̆ı̆ halinde, diğer taraftan burada okunan muhaliflerin tenkit yazısinda kullanilan ifadeleri birbirlerine ekleyerek benim tarifimle karşılaştırırsanız, hakikati aksettirmiş olduğum meydana çıkar. Onların sözleri hakikati görmek istikametini kaybetmiş insanların hareketinden başka birşey değildir. Benim sözlerimde kalkıpta Meclisi terketmeye sebep teşkil edecek mâna var mıdır?" 42

Kürsüye gelenlerden CHP Genel Başkanvekili Şükrü Saraçoğlu, “Okunan nutuk o şekilde tertip ve tanzim edilmişti ki ne kadar simsiyah yazmak mümkünse o kadar simsiyah yazılmıs ve ne kadar kapkara bir neticeye varmak lazımsa o kadar kapkara bir neticeye varmıştır" diyerek suçu DP'ye atmışt1. ${ }^{43}$

Bu hadisede görüldüğü üzere beş ay önceki genel seçimlerde yaşanan usulsüzlüklerle taraflar arasında tırmanan gerilim bütçe görüşmeleriyle krize dönüşmüş, çok partili parlamenter rejime geçiş konusundaki kaygılar artmıştı. Yeni Başbakan Peker azınlık olarak gördüğü DP'yi uslu olmaya çağırmıştı. Fakat DP'liler, demokratik bir sistemin gereği olarak tenkit haklarını sonuna kadar kullanmaya kararlıydı. Bu konuda ödün vermeyeceklerini Meclisi terk ederek gösteren Demokratların bu kararı adeta şok etkisi yarattı. İktidar, karşı fikirlere tahammül gösterme konusunda iyi sinyaller vermemişti. Bununla birlikte bazı CHP'lilerin Peker'i hatalı bulması, iktidar kanadında sertlik yanlısı politikaların bütünüyle benimsenmediğini de göstermişti.

\section{Olayın Yansımaları}

Demokratların Meclisi terk etmesiyle sonuçlanan ilk gün görüşmeleri basında geniş yer buldu. Cumhuriyet olağanüstü gelişmeleri "Mecliste Hadiseli Bir Gün" manşetiyle duyurdu. Mecliste firtınalı sahneler yaşandığına temasla bütçe görüşmelerinin yerini parti çatışmalarının aldığını ifade etti. ${ }^{44}$ Vatan, "Demokratlar, Meclisi terkettiler" ana başlığıyla çıktı. ${ }^{45}$ Ulus, "Çok Çirkin Bir Jest" manşetine yer verdi. Bütçe görüşülürken haksız ithamlarda bulunan Demokratların Başbakan'ın cevabını bahane ederek Meclisi terk etmelerinin üzüntüyle karşılandığı açıklandı. ${ }^{46}$ Akşam gazetesi olayı, "Bütçe müzakeresi gürültülü bir oturumla başladı" başlığıyla duyurmuş, görüşmeleri nakletmekle birlikte yorum yapmaktan kaçınmıştı. ${ }^{47}$

\footnotetext{
42 Tutanak Dergisi, a.g.e., s.28-29.

43 Tutanak Dergisi, a.g.e., s.42.

44 Cumhuriyet, 19 Aralık 1946.

45 Vatan, 19 Aralık 1946.

46 Ulus, 19 Aralık 1946.

47 Akşam, 19 Aralık 1946.
} 
CHP çevreleri muhalefetin Meclisi terk etmesini "çirkin bir hareket" olarak yorumlamışlardı. Nihat Erim, CHP yanlısı Ulus'ta bu yaklaşımı şöyle ortaya koydu: “ $B u$ çirkin hareketle Cumhuriyet tarihinde ilk defa karşılaşmış bulunuyoruz. Dün bütçe görüşmelerinin başlaması münasebetile Başbakanın yaptı̆̆ı demeci bahane ederek Demokratlar ve bir, iki bağımsız milletvekili BMM salonunu bırakıp çıktılar. Bu hareket tarzını biz çirkin buluyoruz. Çünkü bir milletvekilini vazifesini yapmaktan alıkoyacak hiçbir manevî engel, hiçbir maddî cebir ve baskl tasavvur olunamaz."

20 Aralık’ta ilk sayısı çıkan Kuvvet gazetesinde, Fuat Köprülü’nün Başbakan Peker'e cevabını içeren "Kuru Tehditlerden Vazgeçiniz" adlı yazısı yayınlandı. Köprülü yazısında hükümete şu çağrıda bulundu: "Demokratların memlekette bir anarşi havası yarattığına inanıyorsanız hemen vazifenizi yapınız, suçluları mahkemeye veriniz ve Demokrat Parti'yi kapatınız."49

CHP milletvekili Tanrı̈̈ver'in o anın havası içinde beklenmedik bir şekilde Peker'e yönelik kullandığı sözler basının ilgisini çekmişti. Tasvir, Tanrı̈̈ver'in konuşmasını "Hamdullah Suphi Başbakan’ı itham etti” başlığıyla okuyucularına duyurdu..$^{50}$ Cumhuriyet, daha 1lımlı olarak "H. Partisi milletvekili Hamdullah Suphi Başbakanı haksız buldu" ifadesini tercih etti. ${ }^{51}$ Vatan, "Hamdullah Suphi, Başbakanın sözlerini mevkiile uygun bulmadı" başlığına yer verdi. ${ }^{52}$

Nadir Nadi, Mecliste yaşanan sıcak anları, “Demokrasiye veda mı?” başlıklı yazısıyla değerlendirdi. Bir muhalefet partisinin ilk kez hükümeti eleştirerek devlet idaresine yapıcı yol vermesi beklenen bütçe görüşmelerinin çıkmaza girdiğini söyledi. Nadi, alınganlık gösterdiğini düşündüğü muhalif partiyi şöyle tenkit etti:

"Küçük muhalefet grubunu ele alarak hırpalamayı doğru bulanlardan değiliz. Fakat açık konuşmak lazımsa, ikide bir Meclis salonunu terk eden bu vatandaşların hareketini alkışlamak da içimizden gelmiyor... Bir Başvekilin "mariz ve nevropat" demesiyle demokratların tahammül gücü tükenecek miydi? Neden onlar da kürsüye çılkp "Nevropat sensin" diye haykırmıyorlar? Eteklerinden çeken, ă̆ızlarını tıkayan mı var? Bu gibi asabi tabirleri sevmiyorlarsa Başbakanın sözlerini reddederek bildikleri dille de konuşamazlar mıydı? Altmış kişilik bir grup vakıa küçük bir ekalliyettir. Fakat varlığını göstermek şartıyla hiç de azımsanacak bir kuvvet değildir. " ${ }_{33}$

48 Nihat Erim, "Meclisi terketmek vazifeden kaçmaktır”, Ulus, 19 Aralık 1946.

49 Fuat Köprülü, "Kuru Tehditlerden Vazgeçiniz”, Kuvvet, 20 Aralık 1946.

50 Tasvir, 19 Aralık 1946.

51 Cumhuriyet, 19 Aralık 1946.

52 Vatan, 19 Aralık 1946., Genel olarak Peker'in muhalefete yönelik tavrını doğru bulmayan Tanrı̈ver, bu düşüncesini ona şu sözle ifade etmişti: "Muhalifler bize tahta kılıç çıkarıyor, biz ise tank çıkarıyoruz." Bkz.; Asım Us, a.g.e., s.627.

53 Nadir Nadi, “Demokrasiye veda mı?”, Cumhuriyet, 20 Aralık 1946. 
Nadi, olayların bu şekilde cereyan etmesinin bütün sorumluluğunu DP'ye yüklememiş, Başbakan'ın tutumu nezdinde iktidarı şu ifadelerle hedef almıştı:

"Evvelki günkü Meclis patırtılarından edindiğimiz intiba ĕger bizi aldatmiyorsa, Halk Partisinin muhalefet hakkındaki fikri biraz gariptir. Demokrat Parti milletvekilleri kalksın, kürsüye gelerek hükümeti tebrik etsin, yalnız ufak tefek itirazlar ve dileklerle tenkit vazifesini yapsin, isteniyor gibi bir hava seziyoruz. Bu şüphesiz pek iptidai, pek yanlış bir zihniyettir. Dünyanın her yerinde muhalefet muhalefettir. Kanun yollarından ayrılmamak şartiyla hükümet insafsızca hırpalanacaktır. Son karar yalnız halk efkârının kendini açıkça göstermesine bağlldır. Buna tahammül edilemeyecekse demokrasiden bir an önce vazgeçmek lazımdır." ${ }^{4}$

Vatan başyazarı Ahmet Emin Yalman olayda muhalefet yanlısı bir yaklaşım sergiledi. 19 Aralık'taki yazısında parti mücadelesinin "birinin beyaz dediğine diğerinin mutlaka kara demesi" şeklinde bir hal alması durumunda particiliğin gericiliğin mekanizmasına dönüşeceğini ifade etti. Hükümet partisinin görevinin faydalı işlere destek vermek olduğunu, "fena isnatları ve yolsuzlukları örtbas" etmeye çalışmanın disiplin sayılamayacağını vurguladı. Gündemin esas konusu olan bütçeye de değinen Yalman, tek parti iktidarının "iktisadi vasilik" ve "devlet tüccarlığını" kötü usullerle uyguladığını savundu. Üstelik bu zihniyetin değişmediğini, 7 Eylül Kararlarının esas11 incelemeler yapılmadan alındığı iddiasıyla pekiştirdi. Mali ve iktisadi kadroların önlemlerini yetersiz bulan Yalman, zorunlu ihtiyaçlar üzerindeki vergi yükünden ve kırtasiye masraflarından dert yand1. Bu noktada, "milli iradeye dayanan murakabeli bir demokrasi gidişi mertçe" kabul edilmediği ve "tetkiksiz icraata atılmak meyli" durdurulmadığı takdirde iktisadi sıkıntıların giderilemeyeceğini öne sürdü. ${ }^{55}$

Yalman, 24 Aralık’taki yazısında Menderes'e destek çıktı. Onun “müsbet ve faydalı mahiyette" olan tenkitlerinin hükümet tarafından saygı ile karşılanarak ikazlarından faydalanılması gerektiğini belirtti. Peker'i şu sözlerle eleştirdi: "Ĕger Halk Partisinin müfrit mensuplarından biri, tenkide tahammül göstermeyerek Adnan Menderese ve Demokrat Partiye çatarsa karşısında fren diye mesul hükümet başkanını bulması lazım gelirdi... Pekerin bizzat ani bir infial ve hiddete kapılması ve tenkide karşı bu kadar tahammülsüzlük göstermesi; cidden elim ve hazin bir manzaradır." 56

DP'nin muhalefetini yerinde bulan Yalman, bunun demokrasi prensiplerinin yerleşmesi bakımından değerli olduğunu ifade etmiş, aksi halde ortaya çıkacak manzarayı şöyle resmetmişti: "Eğer parti, Halk Partisinin keyfi hareketleri ve tecavüzleri karşısında boyun eğmek, vakit vakit kürsüde bir şeyler söylemek, rey sırası gelince serbest kanaate göre reyini kullanmak gibi menfi bir yol takip edecek olursa tek parti

54 A.e.

55 Ahmet Emin Yalman, "Bütçe müzakeresinden umumî ilhamlar", Vatan, 19 Aralık 1946.

56 Ahmet Emin Yalman, "Vaziyet tam manasıyla berraklaşmağa muhtaç", Vatan, 24 Aralık 1946. 
ruhunun olduğu gibi devamına yardakçılık etmiş ve sadece ona bir nikap hizmetini görmüş̧ olur." 57

Necmettin Sadak, 22 Aralık tarihli makalesinde olaydan dolayı Demokratları eleştirdi. Sadak, Fransız İhtilal Meclisinde Mirabeau’nun meşhur “Biz burada milletin iradesiyle bulunuyoruz, buradan ancak süngü kuvvetiyle çıkarız" sözüne atfen DP'yi, "hiç yoktan yerini boş bırakıp gitmeyi huy edinmek" ile itham etti. Muhalefet partisinin tenkitlerinde insafsız ve ölçüsüz olabileceğini, ancak çoğunluk partisinin de hiçbir demokraside bu tenkitlere boyun eğmeyeceğini belirtti. Meclisin terk edilmesini manasız bulan Sadak, DP'nin alınganlık gösterdiği düşüncesindeydi. ${ }^{58}$ Sadak, başka bir yazısında Demokratların halen Meclise katılmamalarından hareketle Başbakan'a kızarak böyle bir boykotta bulunulmasının çocukça bir hareket sayılacağını ifade etti. ${ }^{59}$

Cem Eroğul'a göre bu olay çok partili demokrasiye geçiş döneminin en önemli bunalımıyd1. ${ }^{60}$ Mahmut Goloğlu, Peker'in yaptığı konuşmada kullandığı sözlere tepki gösteren DP'lilerin Meclis toplantılarını terk etmeleriyle neticelenen olayın demokrasiye geçiş tarihine "Psikopat Olayı" şeklinde geçtiğini ifade etmişti. ${ }^{61}$ Metin Toker, bu sancılı süreci "Psikopat Fırtınası" olarak adlandırdı. ${ }^{62}$

Mahmut Goloğlu'na göre bazı CHP'liler gibi kamuoyu da bu olayda DP'lilerden yana tavır almıştı. ${ }^{63}$ Asım Us, bu olay vesilesiyle Menderes ve muhalefeti sorumlu görenler arasındaydı. Us, hatıra notlarında Menderes'in yaptığı bütçe konuşmasının Halk Partisi ve hükümetine karşı "yıkıcı bir zihniyetle akla gelen ölçülü ve ölçüsüz bütün itirazları" toplayan bir konuşma olduğunu, Peker'in bu ruh halini açıklamak için "psikopat" kelimesini kullandığını ifade etti. Menderes ve Demokratların bütçe komisyonunda yapılan görüşmelere katılmadıklarını, buna karşın bütçe genel kurulda görüşülürken propaganda gösterisine koyulduklarını, bunun "ruhi bir marazın mevcudiyetini ispat eden fiilî bir delil" sayılabileceğini öne sürdü. Demokratların genel kurul salonunu terk etmesinin hayretle karşılandığını aktaran Us, bu davranışın önceden planlanmış olabileceğini şöyle ortaya koydu: "Recep Peker'in sözlerinde hakaret manası çıkarmak için daha evvelden muhalifler arasında verilmiş bir karar ile obstrüksiyona bahane aranmış olmak lazım gelirdi. Ekseriyet partisi içtüzük hüküm-

57 A.e.

58 Necmettin Sadak, "Bir Demokrat partili düşüncesile dahi..”, Akşam, 22 Aralık 1946.

59 Necmettin Sadak, "Demokrat partisindeki kararsızlık ne gibi düşünceler uyandırıyor”, Akşam, 24 Aralik 1946.

60 Eroğul, bu tespitini "çok partili demokrasi rejimini yerleştirme gayretlerinin karşılaştığı en ciddi bunalımın başlangıcı” ifadesiyle ortaya koydu. Bkz.; Cem Eroğul: Demokrat Parti Tarihi ve İdeolojisi, 3. bs., Ankara, İmge Kitabevi, 1998, s.45.

61 Goloğlu, a.g.e., s.176.

62 Toker, a.g.e., s.222.

63 Goloğlu, a.g.e., s.176-177. 
lerine aykırı olarak yazll tenkitleri bir saatten fazla bir zaman sira ile dinledikleri hâlde cevap sırast gelince onların salondan çekilip gitmeleri başka türlü bir surette tefsir olunamazdl. ${ }^{\circ 4}$

\section{Demokrat Partisiz Oturumlarda Tenkitler ve Yanıtları}

DP milletvekillerinin genel kurul salonunu terk etmelerinden sonraki 19 Aralık gününde bütçe görüşmelerine devam edildi. DP'liler salonda yoktu ve görüşmelere katılıp katılmayacakları bilinmiyordu. Demokratlar daha önce de Meclisi terk etmiş ancak ertesi oturumlarda yerlerini almışlardı. Anlaşılan bu defa farklı bir tutum söz konusuydu.

Kürsüye gelen CHP Bütçe Komisyonu sözcüsü Münir Birsel, DP sözcüsü Menderes'in bir gün önceki Milli Savunma Bakanlığı bütçesi eleştirilerine cevap verdi. Barış dönemi bütçesi olan 1938 ile 1947 yılı bütçesi kıyaslanırsa milli savunma ödeneğinin genel bütçe içerisindeki paylarının benzerlik göstereceğini belirtti. Savaş yıllarında \% 50'nin üzerine çıkan milli savunma giderlerinin zamanla azaldığını, böylece diğer bakanlıklara daha fazla ödenek ayrılabildiğini söyledi. 1938'e kıyasla \% 350 artan genel bütçede milli eğitime ayrılan ödeneğin \% 712 arttığını ifade etti. ${ }^{65}$

20 Aralık 1946'da İçişleri Bakanlığ bütçesi görüşüldü. Bakanlık bütçesi 1946'ya nazaran 6 milyon lira artışla 18 milyon lira olarak kabul edilmişti. Bununla birlikte giderlerde kısıntı yapmak amacıyla bucak çalışanlarının da olduğu 568 memur L cetveline ${ }^{66}$ alınmıştı. Bucaklardaki kadroların yetersizliğinden yakınan bazı milletvekilleri, bu kararı eleştirmişlerdi. ${ }^{67}$

23 Aralık tarihli oturumda Maliye Bakanlı̆̆ bütçesi görüşüldü. CHP Bursa milletvekili Faik Yılmazipek tasarruf meselesine eğildi. Memurların çalışma saatlerinin arttırılmasını ve tasarruf için yeni memur alınmamasını savundu. Ayrıca yurtiçinde kazanılan paranın yurtdışına çıkarılması engellenmeli, bütçe yılı sonunda kullanılmayan ödenekler harcanmamalı, kırtasiyecilik yükü azaltılmalı ve ödemeler tek elden yapılarak vergi verimi arttırılmalıydı. ${ }^{68}$

Görüşmelerde Maliye Bakanı Halit Nazmi Keşmir de söz aldı. Önceki konuşmasında 1 milyarı aşan bütçede 30 milyon lira tasarruf sağlandığını açıklamış, rakam büyük olmamasına rağmen bütçede indirmeler yapmak bakımından bu çabanın önem taşıdığını ifade etmiş̧ti. Demokrat Parti adına bütçe konuşmasını yapan Men-

64 Us, a.g.e., s.624-625.

65 T.B.M.M.,Tutanak Dergisi, Dönem:VIII, Cilt:3, B:19, 19.12.1946, s.308-309.

66 L cetveli memurlara ait olan, fiili kadroda olmayıp ihtiyaç olduğunda karşılığı bütçeye konulan kadroları içermektedir.

67 T.B.M.M.,Tutanak Dergisi, Dönem:VIII, Cilt:3, B:20, 20.12.1946, s.320-321.

68 T.B.M.M.,Tutanak Dergisi, Dönem:VIII, Cilt:3, B:21, 23.12.1946, s.366-369. 
deres, vasıtalı vergiler arasında yer alan tüketim ve muamele vergilerinden uzak durulması gerektiğini söylemişti. Maliye Bakanı bu konuya açıklık getirdi. Gelir vergisi sistemi üzerinde çalışmaların sürdüğünü, bu çalışma sonunda tüketim ve muamele vergilerinde indirmelerin mümkün olacağını, ancak bu vergilerin tamamıyla kaldırılmasının söz konusu olmadığını belirtti. ${ }^{69}$

Milli Eğitim Bakanlığı bütçesi görüşmelerinde, Köy Enstitülerine yönelik ciddi eleştiriler yapıldı. DP milletvekillerinin yer almadığı görüşmelerde, CHP'nin bir kolu gibi algılanan Köy Enstitülerinin, CHP milletvekilleri tarafından eleştirilmesi dikkat çekti. Genellikle, enstitü mezunlarının bilgisiz oldukları ima edilerek gittikleri yerlerde faydalı olamayacakları vurgulanmıştı. CHP Çanakkale milletvekili Nurettin Ünen, "Ve şu zihniyeti bilmeleri lazımdır ki, Türk köylüsü böyle yarım yamalak yetişenlerin bilgisine ihtiyaç gösterecek kadar aşağl seviyede değildir" sözüyle, Köy Enstitülerine duyduğu tepkiyi dile getirdi. ${ }^{70}$

Köy Enstitülerinin kuruluş amacı köylere elverişli öğretmen yetiştirmek olduğu halde bu kurumlarda "komünist, sosyalist ve dinsizlik yanlısı" eğitimlerin yapıldı̆̆ iddia ediliyordu. ${ }^{71}$

Enstitülere yönelik eleştiriler hakkında Milli Eğitim Bakanı Reşat Şemsettin Sirer de açıklamalarda bulundu. Sirer, 40 bin köyden 26 bininde okul binası, 32 bininde ise eğitmen vasıflı öğretmen olmadığını belirtti. Köylere gönderilecek öğretmenlerin köye kolay uyum sağlayabilmesi için öğrencilerin köy kökenli olması gereğinden bahsetti. Bakana göre Köy Enstitülerinin önemi burada ortaya çıkıyordu. 1946 yılı sonu itibariyle faal olan 21 enstitüden yıllık 3 bin mezun verileceğini, böylece on yıl içinde öğretmen açığının kapatılmasının planlandığını söyledi. ${ }^{72}$

25 Aralık 1946 tarihli DP'lilerin katılmadığı oturumda Bayındırlık Bakanlığı bütçesi görüşüldü. CHP Tunceli milletvekili Necmettin Sahir Sılan, 1947 bütçe yılında Bayındırlık Bakanlığına 1946'ya nazaran 5 milyon lira fazla ödenek ayrıldığı halde bunun yapıcı işleri hayata geçirmek adına yetersiz olduğunu savundu. CHP Seyhan milletvekili Kasım Ener yollar, köprüler ve büyük su işlerine 1946 yılı bütçesine göre daha az ödenek ayrıldığını söyleyerek buna tepki gösterdi. ${ }^{73}$

Bayındırlık Bakanı Cevdet Kerim İncedayı, 1947 yılı Bayındırlık Bakanlığı bütçesinin 1946'ya göre 5 değil 7 milyon lira fazla olduğunu ifade etti. Ayrıca Kasım Ener'in yol ve köprüler ile büyük su işlerine daha az ödenek ayrıldığı sözlerine bütçe rakamlarını bildirerek karşı çıktı. Buna göre bahsedilen işlere önceki bütçeye kıyasla

69 Tutanak Dergisi, a.g.e., s.377-379.

70 Tutanak Dergisi, a.g.e., s.398.

71 T.B.M.M., Tutanak Dergisi, Dönem:VIII, Cilt:3, B:22, 24.12.1946, s.440-456.

72 Tutanak Dergisi, a.g.e., s.460-465.

73 T.B.M.M., Tutanak Dergisi, Dönem:VIII, Cilt:3, B:23, 25.12.1946, s.472-504. 
birer milyon lira fazla ödenek konulduğunu belirtti. Bakan, 15 yılda yapılması tasarlanan işler için 1 milyar 900 milyon liraya ihtiyaç olduğunu, ancak 1947 y1lı bütçesinde bayındırlığa ayrılan 84,5 milyon liranın gerekli ödenek ortalamasının altında kaldığını söyledi. ${ }^{74}$

26 Aralık’taki oturumda Ekonomi Bakanlığı bütçesi hakkında söz alan CHP Niğde milletvekili Hüseyin Ulusoy, devletin sanayi programlarında kar sağlama düşüncesini öne çıkardığını ifade etti. Devletçilik anlayışında, farklı bölgelerin kalkınmasına olanak tanıyacak sanayi programları uygulanması gerektiğini savundu. CHP Gaziantep milletvekili Cemil Sait Barlas, onun aksine devlet işletmelerinin de sermaye ve iktisadi gerekliliklere uyması gerektiğini öne sürdü. Ona göre savaş yıllarında alınan korumacı tedbirlerle devletçilik baskıcı bir yola girmişti. Savaş sonrasının sanayi yatırımları devletçiliğin bu algısından kurtarılmalıydı. ${ }^{75}$

Ekonomi Bakanı Tahsin Bekir Balta, DP sözcüsü Menderes'in KİT'lerin memleket için büyük bir yük oluşturduğu ve devlet kapitalizmine kayan kar zihniyetiyle hareket ettiklerine dair eleştirilerine değindi. Verdiği örnekler ile devletin kurduğu işletmelerin, kapitalizmin öncelikleri olan, en karlı yerde en karlı işleri yapma ilkesine göre hareket etmediğini ileri sürdü. Bir tesisi kurarken devletçilik anlayışına uygun olarak sadece belirli bir maddeyi üretmeyi değil, geri kalmış bölgelerde iş olanakları sağlayarak ekonomik kalkınmayı memleketin her köşesine yaymayı hedeflediklerini söyledi. ${ }^{76}$

Ekonomi Bakanı Balta sözlerine devamla DP'nin, teşekküllerin harcama ve sermayelerinin bilinmediği, bütçe görüşmelerinde bu değerlerin belirtilmediği yolundaki eleştirilerine açıklık getirdi. KIT'lerin genel bütçede yer alan işletmelerden olmadığı için devletin bünyesinden ayrı olarak özel hukuk rejimine tabi olduklarını dile getirdi. Devletçilik anlayışı kapsamında özel teşebbüsün yapamadığı veya karlı bulmadığı işlerin yapılması esastı. Dolayısıyla devletin kuracağı işletmelerin özel teşebbüsün bağlı olduğu ilkelerle idare edilmesi gerekliydi. Bu teşebbüsler, devletin koyduğu sermayeyi kendi mali koşullarıyla işlettiklerinden, devletin genel bütçesinden ayrı bir bütçe ile değerlendirilmeleri doğal karşılanmalıydı. Ekonomi Bakanı, teşekküllerin mali durum ve gelişmelerinin umumi murakabe raporları vasıtasıyla izlenebildiğini söyleyerek, KIT'ler hakkındaki açıklamalarını sonlandırdı. ${ }^{77}$

Sağlık Bakanlığı bütçesi görüşülürken eğitim bütçesinde olduğu gibi ülkenin içinde bulunduğu koşullara ilişkin tablo açıkça ortaya serilmişti. CHP Maraş milletvekili Kamil İdil, sağlık personeli sayısındaki büyük eksikliklere dikkat çekti. Sağlık

74 Tutanak Dergisi, a.g.e., s.506-515.

75 T.B.M.M., Tutanak Dergisi, Dönem:VIII, Cilt:3, B:24, 26.12.1946, s.529-534.

76 Tutanak Dergisi, a.g.e., s.539-542.

77 Tutanak Dergisi, a.g.e., s.543. 
personeli yetiştirmek için kurulan okullara karşın gerekli personelin üçte birinin dahi sağlanamadığını ifade etti. ${ }^{78}$

CHP Giresun milletvekili Galip Zaimoğlu, sağlık alanında gelişmeyi gösteren diğer bir unsur olarak hastane ve yatak sayılarını aktardı. Türkiye'de 10 bin nüfusa 8 yatak düştüğünü, bu oranın İngiltere'de 154, Bulgaristan'da 20 ve Misır'da 15 olduğunu dile getirdi. Sağlık Bakanı Behçet Uz, Zaimoğlu'nun 10 bin nüfusa 8 yatak düştügü sözünü düzelterek, gerçek rakamın 6 olduğunu söyledi. Üstelik 11 bin yatağın yaklaşık 7 bininin İstanbul'da bulunduğunu, bunun üzerinde ayrıca durulması gerektiğini açıkladı. Uygulanacak sağlık planıyla yatak kapasitesinin 40 bine çıkarılması tasarından bahsetti. ${ }^{79}$

İmparatorluktan devralınan kısıtlı sağlık teşkilatının önemli ölçüde geliştirildiğini aktaran Sağlık Bakanı Uz, 1941 yılında 5 milyon lira civarında olan sağlık ödeneğinin 1947 yılı bütçesinde önemli bir artışla 42 milyona yaklaştığını belirtti. Özel İdareler ve belediyelere ait hastanelerin zamanla genel bütçeye dâhil edilmesi planını açıkladı. Ancak bu bütçe imkânları ile hastanelerin genel bütçeye aktarılması, salgın hastalıklarla mücadele, gerekli sağlık personelinin yetiştirilmesi, hastane binalarının yapı$\mathrm{m} ı$ ile araç ve gereçlerin temini konularında çok yetersiz kalınacağına işaret etti. Bu gerekçeleri öne süren Sağlık Bakanı, kendisinden önce söz alan bazı milletvekilleri gibi istisnalar dışında tedavi ücreti alınması gerektiğini savundu. Ayrıca, sistemsel bir düzenleme olarak sağlık sigortası işlevi görecek sağlık sandıklarının oluşturularak, tedavi ücretlerinin bu sandıklardan karşılanması gerektiğini vurguladı. ${ }^{80}$

DP'lilerin katılmadığı görüşmelerde söz alan bazı iktidar partisi milletvekilleri bütçeye ve parti politikalarına yönelik ciddi eleştirilerde bulunmuşlardı. Aslında bu durum tek partili sistem bakımından oldukça doğaldı. Ulus yazarı CHP'li Nihat Erim bu vesileyle Demokratların yokluklarının pek de hissedilmediğini şöyle savundu: "Demokratların meydanı boş bırakıp çekip çekilmeleri bir an için, bütçenin etrafl tahlil ve tenkitlerden mahrum kalacağını hatıra getirebilirdi. Lakin ilk günden beri görüşmeleri yakından takip etmek firsatını bulmuş olanlar görmüşlerdir ki, tenkit ve tahlilde, Meclisteki vazifelerinin başından ayrılmamış olan bă̆ımsızlarla Halk Partili Milletvekilleri birbirleriyle yarış etmektedirler." 81

\section{Uzlaşı Arayışları}

DP milletvekilleri 18 Aralık 1946'da genel kurul salonunu terk etmişlerdi. DP Meclis Grubu 19 Aralık’ta Celal Bayar başkanlığında parti merkezinde bir araya ge-

78 Tutanak Dergisi, a.g.e., s.547-549.

79 Tutanak Dergisi, a.g.e., s.556-575.

80 Tutanak Dergisi, a.g.e., s.572-575.

81 Nihat Erim, "Bütçe görüşmeleri devam ederken”, Ulus, 25 Aralık 1946. 
lerek Meclise katılıp katılmama konusunu değerlendirdi. Toplantı sekiz saat sürdügü halde bir karara varılamamıştı. Demokratlar 20 ve 21 Aralık'ta da toplantılarına devam etti. ${ }^{82} 22$ Aralık itibariyle kararlarında bir değişiklik yoktu. DP teşkilatlarından gelen destek telgraflarının yoğunluğu nihai kararın teşkilatların hislerine göre ayarlanması gerekliliğini doğurmuştu. ${ }^{83}$ Parlamento boykotunun sürmesi iktidar kanadında tedirginliği arttırdı. Vatan, olayın sıcaklığını koruduğu 22 Aralık'ta "Demokratların Meclise gelmemek kararını vermeleri kat'i gibi” başlığını kullanarak bütçe görüşmelerinin DP'siz tamamlanacağı öngörüsünü aktardı. ${ }^{84}$

$\mathrm{Bu}$ arada iki tarafı barıştırma girişimleri hızlanmıştı. CHP Genel Başkanvekili Şükrü Saraçoğlu ve DP'ye yakınlığıyla bilinen İstanbul bağımsız milletvekili Adnan Adıvar DP Genel Başkanı Celal Bayar'la görüşerek anlaşma zemini aramışlardı. Bununla birlikte 22 Aralık'ta çalışmalarına başlayan DP İzmir il kongresinden Başbakan Peker'e çekilen telgrafla özür dilemediği takdirde istifasını vermesi istendi. ${ }^{85} \mathrm{Bu}$ çıkış taraflar arasındaki uzlaşı arayışlarını örseledi. Asım Us, bu telgrafın DP içindeki kargaşadan yararlanmak isteyen "müfrit unsurlar" tarafından çekildiği kanaatindeydi. ${ }^{86}$

İktidar yanlısı Ulus, 22 Aralık itibariyle tansiyonu düşürmek isteyen bir yayın politikası gütmeye başladı. Nihat Erim, üzüntü verici bu olayın sonlandırılması çağrısında bulunan yazısında şöyle dedi: "Demokratik idare sisteminin bundan sonra Türkiyede devamlı surette sağlamlaştırılmasına çalışmak elzemdir. Bu yoldan geri dönmek asla bahis mevzuu olamaz ve Türkiyede ciddiyetle bunu kimse tavsiye edemez. Cumhuriyetimiz için tek refah ve saadet yolu demokrasi yoludur... Bundan sonra aynı hızla ilerlemenin en önemli şartı şudur: Her iki parti de serin kanlılı̆̆ını daima muhafaza etmelidir."

Erim, her iki partiye de demokratik rejimin tesisi konusunda uyarılarda bulunsa da genel olarak DP'ye yönelik tenkitler yaptı. Muhalefetin seçim öncesi dönemden başlayarak iktidara ağır ve çirkin isnatlarda bulunduğuna temasla "bütün bu hücum-

82 Halit Tanyeli, Adnan Topsakaloğlu, İzahlı Demokrat Parti Kronolojisi 1945-1950, İstanbul, İstanbul Matbaası, 1958, s.57., Cumhuriyet, 20-22 Aralık 1946., DP'liler daha önce de böyle bir gündemle toplanmışlardı. 21 Temmuz 1946'da gerçekleştirilen genel seçimlerde yaşanan usulsüzlükler gerekçesiyle bu konuyu değerlendirmişler, neticede Meclise katılma kararı almışlardı.

83 Cumhuriyet, 22 Aralık 1946., Eroğul, a.g.e., s.45.

84 Vatan, 22 Aralık 1946.

85 Tanyeli, a.g.e., s.57-58., Peker'e çekilen telgraf şöyleydi: "Büyük Millet Meclisinde bütçe müzakereleri sırasında DP adına Adnan Menderes tarafından yapılmış olan tenkitleri mariz, bozguncu, psikopat tabirleriyle vasıflandırmanız bizleri son derece rencide etmiştir. 22.12.1946 günü İzmir'de toplanan DP İl Kongresi bu hareketinizi takbih ettiğini ve Demokrat Partiye taziye vermediğiniz takdirde derhal istifa etmenizin lüzumlu bir hareket olacağını bildirir.” Ulus, bu telgrafı "Bakın dı hele! Meğer Recep Peker istifa etmeli imiş” başlığıyla aktardı. Bkz.; Ulus, 23 Aralık 1946.

86 Us, a.g.e., s.626.

87 Nihat Erim, "Vazifeler tek taraflı değil karşılıklıdır”, Ulus, 22 Aralık 1946. 
lar, isnat ve hakaretler karşısında geniş müsamahasını muhafaza eden iktidar, bir an sertleşince tahammülsüzlük göstermek, mızıkçılık etmektir dersek kızmamalıdır. Unutmamak lâzımdır ki bu alanda vazifeler tek taraflı değil, karşılıklıdır" demişti. Demokratların Meclisi terk etmelerini acemilik olarak yorumlayan Erim, bir süredir Meclisten çekilme söylemlerinde bulunmalarına da tepki göstermişti. ${ }^{88}$

\section{İnönü'nün "26 Aralık Tebliği”"}

İki parti arasındaki ihtilafı gidermek isteyen Cumhurbaşkanı İsmet İnönü, 22 Aralık gecesi DP erkânından Bayar ve Köprülü ile ertesi gün CHP Genel Başkanvekili Saraçoğlu ve Başbakan Yardımcısı Mümtaz Ökmen'le görüştü. Ardından Bayar ve Köprülü 24 Aralık'ta Ökmen'le uzun bir görüşme gerçekleştirdi. ${ }^{89}$

Metin Toker bilinenin aksine görüşme teklifinin Demokratlardan geldiğini aktarmıştı. Buna göre DP teşkilatları gibi milletvekili olmayan DP yöneticileri de boykotu destekliyor, sine-i millet söylemleri ortalıkta dolaşıyordu. DP liderleri bu durumdan huzursuzdu. Meclisten çekilme veya Meclis çalışmalarına katılma kararını vermekte zorlanan liderler çıkış yolu olarak Cumhurbaşkanı'nın devreye sokulması gerektiği kanaatine varmışlardı. Ankaralı iş adamı Üzeyir Avunduk arkadaşı CHP'li Mümtaz Ökmen'le görüşerek Demokratların telkinini Çankaya'ya duyurmuştu. Cumhurbaşkanı İnönü, kendi arabuluculuğu şartıyla yumuşama sinyali veren Demokratlar için "Peki, o halde gelsinler, görüşelim" demiş, böylece Bayar ve Köprülü Çankaya’ya çıkmıştı. ${ }^{90}$

Bayar, bu gelişmelerden sonra kendisini telefonla arayan Vatan'a krizin seyri hakkında şu açıklamada bulundu: "Evet Cumhurbaşkanı ile bir görüşme yaptım. Fakat bu hususta şimdilik bir şey söyliyemiyeceğim. Diğer hususat hakkında da söylenecek müsbet bir şey yoktur. Bunu zaman gösterecektir."91 İnönü, ilk girişimlerin ardından 25 Aralık’ta ikinci defa Bayar ve Köprülü’yü Çankaya'ya davet ederek siyasi buhranın çözülmesi ve Meclis çalışmalarının normale dönmesi ricasında bulundu. Bu gelişme iki parti arasındaki anlaşmazlığın sona ermek üzere olduğu şeklinde algılandı. Görüşme vesilesiyle Demokratların benzer olayların yeniden yaşanmaması

88 A.e.

89 Tanyeli, a.g.e., s.58., Cumhuriyet, 25 Aralık 1946.

90 Toker, a.g.e., s.225-226.

91 Vatan, 24 Aralık 1946. 
için hükümetten teminat istedikleri basına yansıd1. ${ }^{92}$ İnönü, Demokratların isteklerine garanti verdi. ${ }^{93}$

Çankaya'daki ikinci görüşmede İnönü'nün yayınlayacağı tebliğ üzerinde de duruldu. İnönü, tebliği yayınlamadan önce Bayar'a göndermişti. Küçük bir değişiklik ricasında bulunan Bayar, kendilerini Cumhurbaşkanı'nın davet ettiği ifadesinin kullanılmasını istemiş, İnönü kabul etmişti. ${ }^{94} 26$ Aralık 1946'da Cumhurbaşkanı'nın partiler üstü gayretlerini içeren bu tebliğ Anadolu Ajansı vasıtasıyla radyodan kamuoyuna duyuruldu. Tebliğde şöyle deniliyordu:

“Cumhurbaşkanı İsmet İnönü, Demokrat Parti Başkanı Celâl Bayar ve [DP] Meclis Grubu Başkanvekili Fuat Köprülü’yü davet ederek Büyük Millet Meclisi'ndeki hadise hakkında kendilerinden malumat istemiştir. Parti [ve Grup] başkanları, gördükleri muameleden müteessir olduklarını söylemişlerdir. Cumhurbaşkanı, taraflardan birinin haklı veya haksı olduğu konusu üstünde durmayarak, bir kisım milletvekili arkadaşların müteessir olmalarından kendisinin de teessür duyduğunu bildirmiştir. Karşılıklı saygı ve iyi niyetin vücudüne, her iki tarafla yakın temasından dolayı katiyen emin olduğunu bildiren Cumhurbaşkani, şikâyet tezahürünün kâfi görülmesini ve Mecliste normal çalışmanın temin olunmasını Başkanlardan rica etmiştir." ${ }^{5}$

Cumhurbaşkanı ve hükümet temsilcileriyle yapılan temasların ardından toplanan DP Meclis Grubu, ittifakla Meclise katılma kararı ald1. ${ }^{96}$ Böylece dokuz günlük parlamento bunalımı sona ermiş, taraflar arasındaki uzlaşmanın "ilk güzel örneği" sergilenmişti. ${ }^{97}$ Demokratların, İnönü'nün arabuluculuğu neticesinde Meclise girme kararı aldığı anlaşılıyordu. Fuat Köprülü, "Bir siyasî buhranın sonu” adlı makalesinde İnönü’nün bu rolünü şöyle takdir etti: “Anayasanın kendisine tevdi ettiği yüksek vazifesi itibarlyla partilerin ve parti mücadelelerinin üstünde kalması icap eden Cumhurbaşkanın son tebliği, memleketin yüksek siyasetinde daima nazım ve hakem rolünü ifa ile mükellef tarafsız bir devlet reisine yaklşacak bir mahiyettedir." 98

92 Cumhuriyet, 26 Aralık 1946., Vatan, 26 Aralık 1946., Goloğlu, a.g.e., s.176-177., Tanyeli, a.g.e., s.58., Daha önce DP milletvekillerinin tenkitlerini şiddetlendirmesi konusunda telkinlerde bulunan teşkilatlar, bu olay vesilesiyle gösterilen muhalefete tam destek vermişlerdi. Teşkilatlarda görülen heyecanın yatı̧̧ması sebebiyle katılımın birkaç gün geciktirileceği kanaatini aktaran Cumhuriyet gazetesi Demokratların 25 Aralık itibariyle Meclise katılmalarını öngörmüştü. Bkz.; Cumhuriyet, 24 Aralık 1946.

93 Mustafa Albayrak, Türk Siyasi Tarihinde Demokrat Parti (1946-1960), Ankara, Phoenix Yayınevi, 2004, s.99.

94 Toker, a.g.e., s.226-227.

95 Cumhuriyet, 27 Aralık 1946.

96 A.e.

97 Albayrak, a.g.e., s.100.

98 Fuat Köprülü, "Bir siyasî buhranın sonu”, Kuvvet, 27 Aralık 1946. 
Köprülü yazısında ayrıca DP'nin çekildiği bir ortamda Meclisin tek partili bir görüntü çizdiğine temasla bu durumun "siyasi bir buhran" olarak adlandırılabileceğini öne sürdü. Bu olayın iktidar kanadında yeni bir zihniyet değişikliğine sebep olması ümidini aktard1. ${ }^{99}$

Necmettin Sadak, uzlaşıyı "Büyük Şefin Büyük hareketi” olarak yorumladı. ${ }^{100}$ Vatan yazarı Mümtaz Faik Fenik de bu olayın yatışmasında Cumhurbaşkanı'nın rolüne dikkat çekenler arasındaydı. Fenik, Menderes'in rakamlara ve olaylara dayanarak yaptığ 1 tenkitlere karşın Başbakan Peker'in ağır ifadeler kullanmasıyla ortaya çıkan siyasi buhranın, Cumhurbaşkanın iki taraf arasında yaptığ 1 temaslar neticesinde aşıldığını ifade etti. ${ }^{101}$ Fenik, 29 Aralık'taki yazısında ise DP'nin Meclise dönerek demokrasi davasına hizmet ettiğini belirtti. Partinin memleket içinde kökleştiğini aktaran Fenik, bunun aracılık girişimlerine etki yaptığını, böylece iktidarın DP'nin ihmal edilemez bir güç olduğunu anladığını savundu. ${ }^{102}$

Nadir Nadi, parlamento bunalımının son bulmasını "Kriz Bitti” makalesiyle değerlendirdi. Krizin Cumhurbaşkanı'nın isabetli girişimiyle aşıldığına değinen Nadi, bu olay sayesinde parti ve devlet başkanlığı görevlerinin birbirinden ayrı tutulması fikrinin anlam kazandığını belirtti. Böylece genç demokrasinin yeniden normal gelişme imkânına kavuştuğunun altını çizdi. Meclise katılma kararı aldıkları için Demokratlara övgüde bulunan Nadi, sayıları az da olsa varlıkları ile büyük katkıda bulunduklarını belirtmiş, "Yarınki Türkiye onlara çok şeyler borçlu olacaktır" demişti. ${ }^{103}$

Ulus, krizin sonlanmasını "Cumhurbaşkanın İlgisi” başlığıyla aktardı. Yazıda DP'lilerin Peker'in konuşmasına alınarak Meclisi terk etmeleriyle başlayan olayın derin tepkilere neden olduğu, bazı vatandaşların Meclise katılmayan Demokratları vazifeden kaçmakla itham ettikleri belirtilmişti. Ayrıca böyle olayların bir daha yaşanmaması gereken "acemilik devri rahatsızlıkları” sayılması gerektiği vurgulanmişt1. ${ }^{104}$

Fuat Köprülü başka bir yazısında Cumhurbaşkanı'nın teminatına istinaden hükümetin DP'ye beslediği iyi niyetin maddi delillerini görmek istediklerini belirtti. İdare mekanizmasının CHP lehine işleyen bir görüntü arz ettiğine temasla demokrat memleketlerde olduğu üzere tarafsız ve dürüst bir idare beklediklerinin altını çizdi. ${ }^{105}$

\footnotetext{
99 A.e.

100 Necmettin Sadak, "Büyük Şefin Büyük hareketi”, Akşam, 28 Aralık 1946.

101 Mümtaz Faik Fenik, "İki Parti Arasında Normal Çalışma Devri”, Vatan, 28 Aralık 1946.

102 Mümtaz Faik Fenik, "D.Partinin elde ettiği kazanç”, Vatan, 29 Aralık 1946.

103 Nadir Nadi, "Kriz Bitti”, Cumhuriyet, 28 Aralık 1946.

104 Ulus, 28 Aralık 1946.

105 Fuat Köprülü, "Karşılıklı İtimad”, Kuvvet, 29 Aralık 1946.
} 
Peker karşıtlığıyla bilinen CHP'li Nihat Erim, krizin başında eleştiri oklarını muhalefete yönelterek onu savunan bir görüntü çizmişti. Ancak kriz aşıldıktan sonraki yazılarında çok partili rejime geçişte Peker yönetiminin sorumluluğuna dikkat çekmişti. Erim, 30 Aralık tarihli "Ya bu deveyi gütmeli ya..." yazısında Cumhurbaşkanı'nın partiler üstü rolüne temasla tebliğin tarafların iyi niyetinin göstergesi sayılması gerektiğini belirtti. Bu tecrübenin çok partili demokratik sistemin geleceği bakımindan firsat olduğunu savunan Erim yazısını şöyle tamamladı: "Girdiğimiz yoldan dönüş yoktur. Türkiye için sırf şahıs otoritesine dayanan Asyaî sisteme tekrar dönmek kaçınılacak bir felaket sayılmalıdır. Kendi kendimize vereceğimiz parola şu olmalıdır: "Ya bu deveyi gütmeli, ya bu diyardan gitmeli! Bu deveyi elbirliğiyle güdeceğiz."106

Kriz günlerinde iktidar ve muhalefet arasında yaşanan gerginlik bağları koparma seviyesine getirmişti. DP'nin tamamen Meclisten çekilmesi halinde çok partili demokrasiye geçiş dönemi askıda kalabilir veya yeniden tek partili rejime dönülebilirdi. Dolayısıyla bu tehlikeyi sezenler araya girmiş, özellikle partiler üstü bir görüntü çizen Cumhurbaşkanı'nın gayretleri etkili olmuştu. İnönü'nün tebliği özellikle muhalefet kanadında memnuniyetle karşılandı. Bundan sonra Cumhurbaşkanı'nın parti genel başkanlığını terk etmesi ve hükümetin DP'ye karşı daha anlayışlı bir yaklaşım sergilemesi beklentileri doğmuştu. Değişime ayak uyduramayan Peker açısından sonun başlangıcı görülmüştü.

\section{Demokrat Parti Muhalefetinde Bütçe Görüşmeleri}

Demokratlar dokuz günlük aranın ardından 27 Aralık 1946'da genel kurul salonuna döndü. O gün Tarım Bakanlığı bütçesi görüşülüyordu. Söz alan DP Eskişehir milletvekili Hasan Polatkan, nüfusun \% 81'inin çiftçi olduğu bir ülkede tarıma bir milyarı aşan bütçeden 29 milyon lira pay ayrıldığını söyleyerek, bu durumu eleştirdi. Üstelik aylık ve idare masraflarının çıkarılmasından sonra kalan ödeneğin zirai kalkınma açısından yetersiz olduğunu ifade etti. ${ }^{107}$

Eleştirilerini sürdüren Polatkan, memleketin üretim ve ziraat şekli bakımından " iptidailikten” kurtulamadığını, nüfus ve hektar başına isabet eden tarımsal verimin "orta çağ hududunu” aşamadığını öne sürdü. Sulama işleri, toprağın kuvvetlendirilmesi, iyi tohum kullanılması, zirai işletmelerin zamanın koşullarına uygun aletler edinmesi, haşereler ve hastalıklarla mücadele edilmesi çalışmalarına ağırlık verilmesi gerektiğini, ancak Ziraat Bakanlığının bu sahalarda çalışan ve başarılı olan bir teşkilat olmadığını savundu. ${ }^{108}$

106 Nihat Erim, "Ya bu deveyi gütmeli ya..." Ulus, 30 Aralık 1946.

107 T.B.M.M., Tutanak Dergisi, Dönem:VIII, Cilt:3, B:25, 27.12.1946, s.610-611.

108 Tutanak Dergisi, a.g.e., s.611-613. 
DP Eskişehir milletvekili Emin Sazak da tarım bütçesini değerlendirenler arasındaydı. Bakanlığa ağır eleştirilerde bulunan Sazak, Zirai Donatım Kurumunun yurt dışından gelecek malların döviz inhisarını dahi eline aldığı iddiasında bulundu. Teknik ziraat adı altında 30 kişiye bir traktör dağıtıldığından bahisle traktörün günde 30 dönüm yer sürdügünü, hâlbuki 100 dönüm yeri olan küçük çiftçilerin traktör yerine öküz ve atla takviye edilmesi gerektiğini savundu. ${ }^{109}$

Eleştiri dozunu arttıran Sazak, hükümet ve bakanlığın üretimi azaltmak için elinden geleni yaptığını savundu. Çok buğday götürünce almamaya başladığını, mazot ve traktör vermediğini söyledi. Tarım Bakanı Faik Kurdoğlu için "Kurdoğlu arkadaşımı ben vekil oldum. En yüksek düşünen benim demesin, nihayet o da bir insandır" diyerek, eleştirilerinin dikkate alınmasını istedi. Mera konusunda "lakaytl1k" olduğunu belirtti. Kendi şehri Eskişehir'den örnek veren Sazak, 200-300 haneli bir köyün 5 bin dönüm merası içinde hayvanların otladığını, ancak çeşitli sebeplerin yanında toprak dağıtmak zihniyetiyle köy merasının gittiğini ifade etti. ${ }^{110}$

Kürsüye gelen Tarım Bakanı Faik Kurdoğlu, başta Adnan Menderes olmak üzere değerlendirmede bulunanlara teşekkür ettikten sonra Menderes için "Bu arkadaşa göre ziraat mevzuu henüz ele alınmış bile değildir" dedi. Emin Sazak'1n tenkitlerini dikkate almadığını gösteren Kurdoğlu, Menderes'i fazlasıyla ciddiye almıştı. Bakan, Meşrutiyet devrinin geniş sahası içinde olan 1909 yılı bütçesinde tarım, orman ve madenciliğe 345 bin lira ödenek ayrıldığını, cumhuriyetin ilk yılında ise sadece tarıma ayrılan bütçenin 7 milyon 330 bin olduğunu, cumhuriyetin yirmi üçüncü yılında tarım ve ormancılığı içeren bütçenin 42,5 milyona ulaştığını söyledi. Genel nüfusun \%75,61'ini oluşturan köy, bucak ve kasabada yaşayan vatandaşlar için yapılmış ve yapılmakta olan hizmetlerin sadece Tarım Bakanlığı bütçesi bölümleri üzerinden incelenmesini doğru bulmadığını ifade etti. Su işleri, demiryolu işleri, yollar, bankalar ve fabrikalar gibi milyarlar dökülen bütün müspet işlerin onların ihtiyaçları için yapıldığını söyledi. Cumhuriyet rejimi kurulduğundan beri milli savunma ile beraber "en çok köylü ve çiftçi için ve ona Partimizin Ebedî Şefi Atatürk'ün işaret ettiği istikâmette hizmet için emek verilmiştir" dedi. Durum böyle iken Menderes'in sözünün gerçeği yansıtmadığını savundu. ${ }^{111}$

Kurdoğlu, Menderes'e yönelik açıklamalarının ardından DP Denizli Milletvekili Reşat Aydınlı'nın Tarım Bakanlığını ilgilendiren sözlü sorularını cevaplandırdı. Aydınlı bir sorusunda, "Geçen yıl buğdayı daha pahalı alıyordunuz, bu yıl neden ucuza alınmaktadır? Bu hayat pahalılığı karşısında hemen hemen yegâne geçim kaynă̆

109 Tutanak Dergisi, a.g.e., s.620-621.

110 Tutanak Dergisi, a.g.e., s.621-622.

111 Tutanak Dergisi, a.g.e., s.638-639. 
olan (Köylümüz için) bu buğdayın fiyatına zam yapmak veya prim vermek kabil midir" demişti. ${ }^{112}$

Tarım Bakanı cevaben buğday fiyatlarını belirli bir nispetin altına düşürmemekle vazifeli Toprak Ofisinin, 22 kuruş olarak belirlediği başfiyatın üzerindeki satışları yasaklamadığını, aksine fiyatların düşmesini önleyen bir sigorta görevi gördüğünü belirtti. Ardından Ofisin, fiyatları arttırma gerekliliğini irdeledi. Bu kapsamda buğday fiyatlarının zaman içindeki seyrini toptan genel fiyatlarla kıyaslayan Bakan, Toprak Ofisi mekanizması sayesinde hiçbir mal için sağlanmayan sigortalı fiyatın buğday için korunduğunu, bu fiyatın toptan eşya ile sınai ve yarı mamul maddeler fiyatlarında gerçekleşen artışın oldukça üzerinde bulunduğunu dile getirdi. Durumu bu şekilde ortaya koyduktan sonra buğday piyasasının merkezi sayılan New York rakamlarıyla bir karşılaştırma yaptı. Buğday fiyatı New York’ta 9,7 kuruştu. Devalüasyonun yan etkilerine rağmen Toprak Ofisinin sağladığı buğday başfiyatının bunun 8-9 kuruş üzerinde olduğunu belirtti. ${ }^{113}$ Böylece hem Aydınlı'nın hem de söz alan diğer bazı DP milletvekillerinin buğday fiyatlarının düşük tespit edildiğine ilişkin eleştirilerine yanıt vermiş oldu.

Aynı gün Ulaştırma Bakanlığı bütçesinin görüşülmesine başlandı. Ulaştırma Bakanı Şükrü Koçak, o ana dek gelen eleştiri ve soruları değerlendirmek üzere kürsüye geldi. Demokrat Parti sözcüsü Adnan Menderes, bütçenin geneline ilişkin değerlendirmesinde partisinin görüşünü açıklarken dört ay önceki hükümet programında Ulaştırma Bakanlığı çalışma sınırları içinde yapılması düşünülen işlere de temas etmiş, bunların mevcut bütçe imkânlarıyla örtüşmediğini ileri sürmüştü. Ulaştırma Bakanı Koçak, konuşmasının büyük bir bölümünü bu konuya ayırdı.

Koçak, hükümet programında yer alan bütün demiryolu şebekesinin 1slah edileceği vaadinin, "en önemli hatlardan başlayarak" kaydı koyulmak suretiyle tedricen yapılacağına işaret edildiğini, Menderes'in her nedense bu kayda lüzum görmediğini söyledi. Menderes, hükümet programında "Deniz endüstrisini gemi yapacak hale getireceğiz" tarzında bir taahhüt olduğunu ifade etmişti. Koçak, bunun aslının "Deniz endüstrisini süratle gemi yapabilecek duruma getirmek imkânlarını araştıracă̆ı" şeklinde olduğunu, Menderes'in hükümet programındaki ifadelerden bazı fikraları kaldırarak bunları taahhüt çerçevesi içine soktuğunu öne sürdü. Menderes'in ifadelerini "zekâsına ve tetkik kabiliyetine" sığdıramadığını belirtti. ${ }^{114}$

Ulaştırma Bakanı, DP'lilerin bütün konuşmalarında 1938 yılını ferah bir yıl olarak gösterdiklerini, Menderes'in de bir ifadesinde, Devlet Demiryollarının 1938'deki ferahlı durumuna gelebilmesi için bir milyar liraya yakın para harcamak gerektiğini

112 Tutanak Dergisi, a.g.e., s.643.

113 Tutanak Dergisi, a.g.e., s.643-644.

114 Tutanak Dergisi, a.g.e., s.657-658. 
söylediğini, ancak bu çıkarımlarda bulunulurken memleketin üretim toplamı ve demiryolları trafik yükünün hesaba katılmadığına dikkat çekti. 1938'de 12 milyon olan tren kilometrenin 1946'da 24 milyon tren kilometreye çıktığını, buna rağmen ihtiyacın karşılanamadığını ifade etti. Devlet Demiryollarının, 1938 yılı nakil vasıtaları 1939'dan itibaren yetersiz görüldüğü için İngiltere, Amerika ve Almanya' dan lokomotif, yolcu ve yük vagonları satın aldığını, ancak ikiye katlanan tren kilometre grafiği sebebiyle 1938 yılı ferahlığının sağlanamadığını açıkladı. Mevcut ihtiyaçları karşılayabilmek ve bazı atölyeler kurmak için 337 milyon lira kadar bir paraya ihtiyaç duyulduğunu, bunun 90 milyon lirasının tamamen taahhütlere bağlandığını dile getirdi. Bu kapsamda Eskişehir, Sivas ve Arifiye'de yapılacak tesisler ile yenilenecek demiryolu hatlarından bahsetti. ${ }^{115}$

Adnan Menderes, Bütçe Komisyonu raporlarında yıllardan beri kadrolarda tasarruf yapılacağı söylendiği halde yapılamadığı eleştirisinde bulunmuştu. Koçak, Devlet Demiryollarında yapılan kadro tasarrufunun bütçe gerekçesinde maliyetlere aksettirildiğini, böyle olduğu halde DP gazetelerinin yapılan kadro indirmelerini eleştirdiklerini söyledi. ${ }^{116}$

DP'nin dokuz günlük bir aranın ardından katıldığı ilk günün oturumları Ulaştırma Bakanı'nın açıklamalarını takiben olaysız sona erdi. Temkini elden bırakmayan taraflar politik söylemlerden uzak durmuştu. İktisadi konuların dışına çıkmayan muhalefet tarım ve ulaştırma bütçelerinin mali anlayışını sorgulamış, iktidar sözcüleri de tansiyonu yükseltmeden karşılık vermişlerdi.

\section{Eylül Kararları Gölgesinde Ticaret Bakanlığı Bütçesi Görüşmeleri}

Bütçe görüşmeleri 28 Aralık’ta da devam etti. Ticaret Bakanlığı bütçesi görüşmelerinde söz alan DP Kütahya milletvekili Hakkı Gedik, bütçe tasarısına göre bakanlığın bütün giderlerini oluşturduğunu söylediği dış ve iç ticaret servislerinde çalışan kadronun işlerinde ne derece faydalı olduklarını ortaya koyan bir hükümet beyanı veya Bütçe Komisyonu raporu olmadığını söyledi. Ticaret Bakanlığının dış ve iç servislerinin verimli çalışmadıklarını ileri sürdü. ${ }^{117}$

Hakkı Gedik, ticaret yapılan ülkelerden İkinci Dünya Savaşı'nın en yıkıcı etkilerine maruz kalanlarında bile eşya ve hizmet fiyatlarında bir katlık artış söz konusu değil iken Türkiye'de 1939 yılına göre 4-5 katlık bir artış olduğunu söyledi. Bunun başlıca sebeplerini şöyle sıraladı; dizginsiz enflasyon ve emisyon, adil ve verimli olmayan vergi sistemi, bütçe açıklarını kapatmak için yüksek faizli borç siyaseti güdülmesi, İktisadi Devlet Teşekküllerinin rasyonel çalışma şartlarına uymayan düzensiz

115 Tutanak Dergisi, a.g.e., s.658-660.

116 Tutanak Dergisi, a.g.e., s.659.

117 T.B.M.M., Tutanak Dergisi, Dönem:VIII, Cilt:3, B:26, 28.12.1946, s.702. 
idaresi, verimli ve nizaml fiyat kontrol mekanizması kurulmaması, ithalat ve ihracat işlerinin alınan basiretsiz kararlar yüzünden tanzim edilmemesi, üretimin arttırılmaması, hesapsız tüketim temayülünün önlenmemesi.

Gedik, bu sebepler arasında fiyat artışları bakımından vergi, emisyon ve borç meselelerinin özellikle önem taşıdığını ifade etti. Vergi gelirlerinin yetersizliği yüzünden devletlerin emisyona başvurduğunu, buna karşın tedavüle çıkarılan paranın hacmi şiştikçe eşya ve hizmet fiyatlarının da şiştiğini belirtti. Bunu önlemek için ekonomide "kapalı devir" usulünün uygulandığını, bu usulün üç mekanizmasının bulunduğunu, bu mekanizmaların tedavüle arz olunan banknotlardan bir kısmının vergilerle piyasadan geri alınması, tüketimin frenlenmesi ve tasarrufun sağlanması olduğunu söyledi. Böyle mekanizmalar uygulanmadığı için halkın fakirleştiğini savundu. ${ }^{118}$

Eleştirilerini sürdüren Gedik, 7 Eylül Kararlarını, Ticaret Bakanlığının görev ve yetkisinde bulunan iktisadi politika hatalarından biri olarak sundu. Paranın iç kıymetinin düşük, dış kıymetinin yüksek olduğu durumlarda ihracatın güçleşeceğine, bu takdirde devalüasyon usulüne başvurulacağına temasla, paranın düşürülmesi halinde iç fiyatlarda olası yükselişleri önleyici tedbirlerin de önceden düşünülmesi gerektiğini vurguladı. Ancak hükümetin, bu tedbirleri almadığı gibi bazı vergi artışlarıyla fiyatlar1 körüklediğini öne sürdü. ${ }^{119}$

Devalüasyona gerekçe gösterilen, paranın dış kıymetinin yüksek olduğu iddiasının ihracat mallarının satılmamasıyla ölçüldüğünü ifade eden Gedik, son üç yıllık dış ticaret durumu üzerinde durarak devalüasyon kararını sorguladı. Kademeli bir artışla 1943 'te 54 milyon, 1944 'te 67 milyon ve 1945 'te 92 milyon olmak üzere toplamda 213 milyon liralık dış ticaret fazlası verildiğini söyledi. Ayrıca ihracatın ithalattan fazla olması eğiliminin dünya konjonktürü bakımından daha da fazlalaşacağı iddiasında bulundu. İhraç mallarının satıldığı bir ortamda kambiyo rayici üzerinden paranın \% 50 oranında düşürülmesinin mantıklı açıklaması olmadığını savundu. ${ }^{120}$

CHP Diyarbakır milletvekili İhsan Hamit Tigrel, DP'nin hislerine tercüman olduğunu söylediği Hakkı Gedik' in, hayat pahalılığ 1 ve 7 Eylül Kararlarına ilişkin tenkitlerine karşılık verdi. Tigrel, fiyat yükselişlerine nazaran satın alma gücünün arttığı bir durumda hayat pahalılığının söz konusu olamayacağını savundu. DP'lilerin, eşya fiyatlarının hayatı "1stırap verici” raddeye getirdiği şeklindeki iddialarını rakamlarla belgelendirmesi gerektiğini belirten Tigrel, hayat pahalılığı söylemlerinin politika konusu olduğu kanaatindeydi. DP'liler hayat pahalılığını doğuran sebeplerin başında 7 Eylül Kararlarını göstermişti. Tigrel, hükümetin aldığı devalüasyon kararının ihracatın artırılması keyfiyeti, paranın dış ve iç kıymetleri arasında denge sağlanması,

118 Tutanak Dergisi, a.g.e., s.703.

119 Tutanak Dergisi, a.g.e., s.703-704.

120 Tutanak Dergisi, a.g.e., s.704. 
uluslararası iktisadi kuruluşlara girilmesi ve onlardan faydalanılması gerekçelerine dayandığını aktardı. ${ }^{121}$

Vergi konusunun da istismar edildiği görüşünde olan CHP'li Tigrel, vergilerin milli gelire oranı üzerinde durdu. Bu oranın Fransa'da \% 27, Kanada' da \% 28, Amerika' da \% 24, İngiltere'de \% 33 iken Türkiye'de \% 20'nin altında olduğunu açıkladı. Bununla birlikte vergilerin adil bir şekilde düzenlenmediği tenkitini kabul eden Tigril, hükümetin Gelir Vergisi Kanunu üzerinde çalıştığını aktardı. Konuşmasının son kısmında Meclisi denetlemesini bekledikleri Demokratların, "bedbin, kötümser ve fütûr verici" ifadelerde bulunmalarının memleketin ruhunu zehirlediğine bahisle gerçek verilerle eleştiride bulunarak memlekete faydalı hizmetler yapmaları temennisinde bulundu. ${ }^{122}$

Ticaret Bakanlığı bütçesi hakkında son konuşmayı Ticaret Bakanı Atıf İnan gerçekleştirdi. İnan, eleştirilerin odak noktasını oluşturan 7 Eylül Kararlarına geniş yer verdi. İngiltere ve Fransa gibi ülkelerin 1930'lu yıllarda para birimlerini altın esasından ayırdığını, buna uyum sağlayamayan Türkiye'nin ödeme kabiliyeti olmayan, mübadele esasına göre çalışan ülkelerin peşine düştügünü söyledi. Genel ve özel takasa dayalı bu sistemin kamufle edilmiş bir devalüasyon olduğunu belirten Ticaret Bakanı İnan, başta Almanya olmak üzere kliring anlaşmalarıyla çeşitli memleketlere bağlanıldığını, böylece karşı tarafın fiyat hâkimiyeti altına girildiğini dile getirdi. Üstelik bu usulün açığını kullanan birkaç tüccardan meydana gelen takas gruplarının fiyatlara etki ettiklerini öne sürdü. ${ }^{123}$

Celal Bayar'ın Ekonomi Bakanı olduğu 1938 öncesinin “saadet devrinin iktisat idaresi” şeklinde gösterilmek istendiğini belirten İnan, 1939'dan sonraki kararlı uygulamaların "politik istismar" konusu haline getirildiğine temasla "bizim muhalif arkadaşlarımızın istikrara muhalif olduklarını farzetmek lâzımdır” dedi. DP'lilerin övgüyle bahsettiği 1938'den önceki iktisadi kararları eleştiren İnan, şu sözlerle DP lideri Bayar'ı hedef aldı:

"1938 evvelisi Celâl'li iktisat idaresinin yıllarından biz stokları olmayan bir memleket halinde, İkinci Dünya Harbinin başlangıcı olan 1939 yılına girdik... biz 1939 yılına ödeme aczi ile girdik. Maalesef söylüyorum. 1939 harb yılı gelip çatmamış olsaydı bizi borçlarını ödeyemeyen memleketler listesine kaydedeceklerdi... Biz niçin borçlarını ödemeyen memleketler listesine girecektik? Çünkü muhtelif memleketlerin bizde bloke paraları vardı. Mâllarını alıyorduk, paralarını veremiyorduk." 124

121 Tutanak Dergisi, a.g.e., s.708-709.

122 Tutanak Dergisi, a.g.e., s.709-710.

123 Tutanak Dergisi, a.g.e., s.719-720.

124 Tutanak Dergisi, a.g.e., s. 721. 
Savaş yıllarında açık ticaret sahasına girildiğini söyleyen İnan, ilk adım olarak "Takas Limited” kurduklarını, böylece özel takas gruplarından arındıklarını söyledi. 7 Eylül Kararlarının açık ticaretin gereği olarak alındığına işaretle paranın iç ve dış kıymeti arasında bir denge kurulduğunu savundu. Konuşması boyunca DP sözcüsü Adnan Menderes ve DP milletvekili Hakkı Gedik'in hayat pahalılığı ve sefalet temalı tenkitlerine karşılık verme gayretinde olan İnan, Menderes'in, milletin içinde bulunduğu sıkıntılı durumdan "yeni şuur ve hamle" ile kurtulacağı sözüne şöyle tepki gösterdi: "Kim bu yeni şuur ve hamleyi temsil edenler? Elbette 1938 evvelisi cennet ve saadet devrinin Celalli idaresinin muvaffak önderleri. Bunların yanı başında şu stralarda alel ekser kanaat ve görüş birliğiyle, birçok işlerde bir anlayışla mesuliyet paylaştığımı arkadaşlar." 125

Savaş dönemi iktisat anlayışını eleştiren DP'lilere karşılık vermek isteyen Ticaret Bakanı, savaş öncesi dönem için "Celalli idare" ve "saltanat devri" tabirlerini kullanarak dönemin İktisat Bakanı Bayar’a göndermede bulunmuştu. Bu sözleri “yersiz” bulan Vatan yazarı Mümtaz Faik Fenik, İnan'ın makul bir tenkide karşı insaf ve saygı sınırlarını aşan bir karşılık verdiğini savundu. Fenik, Celalli idare olarak anılan devrin Atatürk'ün devri olduğuna bahisle Bakan'a şöyle tepki gösterdi: 'Hiç kimsenin öyle bir devri, değil BMM kürsüsünden, herhangi bir şekilde Celali eşkıyası devrine kıyas etmeğe hakkl, salahiyeti yoktur. Hayır, Atıf Inan, bu devir, Celali devri değildir; bu devir ancak Kemal devridir; bütün bir inkllâp tarihini, beceriksiz, acemi bir politika oyununa alet edip inkar etmek bu memlekette sade sizin değil, kimsenin haddi olamaz." 126

Akşam yazarı Necmettin Sadak, bu tartışmada Ticaret Bakanı'nı haklı görenlerdendi. Sadak, Bayar ve arkadaşlarının uzun yıllar CHP içerisinde politika ürettiklerine bahisle henüz ayrıldıkları partiye karşı daha insaflı olmaları gerektiğini ifade etti. Demokratların sosyal, politik ve ekonomik prensiplerdeki farklılıklardan dolayı değil kızgınlık duydukları için CHP'den ayrıldıklarını öne sürdü. Fikirlerin çatışmadığı bir ortamda "sen, ben" kavgasına düşüldüğünü ifade eden Sadak, hükümet partisi içinden doğan muhalefet partisinin "geçimsizlik, sunilik ve zayıflık" sebebi olduğunu öne sürdü. İktisat Bakanı İnan gibi Bayar dönemi iktisat politikalarına atıfta bulunarak, "Demokrat Partisi Şefi, memleketin ekonomik durumundan başlıca sorumludur. Bugünkü bozukluğun temelini, CHP Íktisat Vekili Celal Bayar atmıştır" dedi. ${ }^{127}$

Demokratların boykotun ardından katıldığı bütçe görüşmeleri Mecliste yeni bir çalışma devri başladığı izlenimine yol açmıştı. Demokratlar devalüasyon odaklı tenkitleriyle inceden inceye hükümete yüklenmişti. Ancak bu yapay bahar havası uzun

125 Tutanak Dergisi, a.g.e., s.721,725.

126 Mümtaz Faik Fenik, “Ticaret Bakanının çok yersiz sözleri”, Vatan, 30 Aralık 1946.

127 Necmettin Sadak, "Samimi olmak ve bütün neticelere önceden katlanmış olmak”, Akşam, 29 Aralık 1946. 
sürmeyecekti. Tarafların Ticaret Bakanlığg bütçesi görüşmelerinde sarf ettiği sözler yeni krizlerin habercisiydi.

\section{Menderes Yeniden Kürsüde}

1947 y1lı bütçe görüşmeleri 30 Aralık 1946'da tamamlandı. Bütçe tasarısının tümü açık oya sunulmadan önce Meclis iç tüzüğünün 110. maddesine istinaden bu konu üzerinde "yana ve karşıya" olmak üzere birer milletvekiline konuşma hakkı tanındı. DP adına söz hakkını Adnan Menderes kullandı. Menderes konuşmasına teşekkürle başladı. Bütçe görüşmeleri boyunca yaptıkları tenkitlere cevap vermek için harcanan mesaiyi takdirle bunu tenkitlerinin değer bulması manasında yorumladı. Bu giriş konuşmasının ardından 18 Aralık tarihli oturumda patlak veren olaya cevap niteliğinde olmak üzere şöyle dedi:

"Şahıslara tecavüz etmek kimsenin inhisarında değildir. Bu vadiye sapanlara aynı ă̆ırlıkta sözlerle mukabele etmek mümkündür ve hatta bir haktır. Böyle bir hakkı kullanmaktan bizi menedecek hiç bir kuvvet yoktur. Ancak cevap vermemek, sükûtla karşılamak suretiyle mevzu haricinde ve şahsiyat vadisinde sarf edilmiş bütün sözleri en lâyı ş̧ekilde karşılamış olacă̆ımıza kaniyiz. Zati müktesebat ve siyasi olgunluğu noksan olanların sözlerine asla ehemmiyet vermeyerek bu yüksek kürsünün vakar ve ciddiyetini muhafaza etmek Demokrat Partinin daima şiarı olacaktır."'128

Bütçenin samimiyeti meselesini yeniden gündeme getiren Menderes, 7 Eylül Kararlarının neden olduğu artışların bütçe tasarısının masraf tahminlerinde nazara alınmadığını verdiği örneklerle ispatlamaya çalıştı. Yıllardır denk olduğu söylenen bütçelerin açıklarla kapanarak, borç yükünü arttırdığını savundu. Bir eleştiri üzerine Maliye Bakanı Halit Nazmi Keşmir'in, Millî Savunmanın Toprak Mahsulleri Ofisine olan borcunun "tüccar alacağı" niteliğinde bir borç olmadığı cevabını verdiğini söyleyen Menderes, Ofisin kâr ve zarar bilançolarıyla hesap vermek zorunda bulunan bir iktisadi kuruluş olduğunu ifade etti. Milli Savunmaya harcanan masraflar konusunda hükümetle birlikte olduklarını, ancak buradaki meselenin bütçe hesaplarının samimiyetiyle ilgili bulunduğunu belirttikten sonra Maliye Bakanı Keşmir’in açıklamalarına rağmen "bütçe tahmin ve hesaplarında fahiş isabetsizlikler yapıldığı yolundaki” görüşlerinin değişmediğini belirtti. ${ }^{129}$

Açıklamalarını sürdüren Menderes, Hükümet programında yer bulan milyarlık işlerin nasıl gerçekleştirileceği hakkında bir hesap ve açıklama olmadığına bahisle eleştirilerde bulundu. Konuşmasının son bölümünde, 18 Aralık’taki nutkunda tartışmalara yol açan ifadeleri üzerinde durdu. DP'nin hesapsız bir program için uygulama imkânı olmadığı şeklinde bir tahlil yaptığını, bunun "karamsar, kötümser ve karanlık"

128 T.B.M.M., Tutanak Dergisi, Dönem:VIII, Cilt:3, B:27, 30.12.1946, s.836-837.

129 Tutanak Dergisi, a.g.e., s.838-839. 
olarak tanımlanarak işin içinden çıkılmaya çalışıldığını savundu. Amaçlarının Hükümet ve CHP politikalarının isabetsiz olduğundan hareketle bütün zorlukların "hamleci ve şuurlu görüş sahibi" yeni bir zihniyetle aşılacağını söylemek olduğunu ifade etti. ${ }^{130}$

Menderes'in ardından kürsüye CHP Bütçe Komisyonu sözcüsü Münir Birsel geldi. Birsel, iç tüzüğe göre Menderes'in hangi gerekçeye dayanarak bütçeye ret veya kabul oyu vereceğini açıklaması gerekirken yeni tartışma konuları açtığını ileri sürdü. $\mathrm{Bu}$ eleştirinin ardından bütçenin esasını teşkil eden ihtiyaçların önemli kısımlarını üç madde halinde sıraladı. Bunlar dünya düzeni sağlanana kadar savunma kuvvetlerinin ayakta tutulması, savaşın getirdiği iktisadi zorlukları önleyecek tedbirlerin alınması ve milli kalkınma hamlelerinin hızla hayata geçirilmesiydi. ${ }^{131}$

Bütçenin samimiyetine inandığını belirten Birsel, defalarca tartışılmasına rağmen bazı fikirleri değiştirmenin zorluğuna işaret etti. Ancak yine de devalüasyon sonrası Milli Savunma Bakanlığı bütçesinde oluşan 8 milyon liralık fark ve bakanlığın Toprak Mahsulleri Ofisine ait olan borcu hakkındaki iddialara cevap verdi. Milli Savunma bütçesinin bir takım farklar içerdiğini ancak bütçenin bakanlık ihtiyaçlarının gerektirdiği şekilde karşılanmasını sağlayacak düzeyde olduğuna inandıklarını belirtti. Borç konusuna temasla kış aylarında yaşanan nakliye zorlukları karşısında tedbiren orduya dağıtılmış olan hububatın, tüketim zamanlarında karşılıklarının gösterileceğini söyledi. Bu kapsamda ordunun elinde bulunan hububat bedelinin 45 milyon lira, Ofise olan borcun ise bunun altında olduğunu ifade etti. Bütçede tasarrufa önem verilmediği iddialarına da cevap veren Birsel, 1700 kadar memur kadrosunun L cetveline alınmasının tasarruftan başka bir şekilde ifade edilemeyeceğini belirtti. ${ }^{132}$

Programını, "kemalist rejimin hududu" ile çizen, "dünyayı hayran bırakan büyük inkılâpları yapan iman ve güveniyle mücehhez olarak, Büyük Ata'nın Kemalizm rejimi içinde yetişmiş" ve sonrasında "fazilet timsali bir Şefi”" başında tutan partinin üyeleri olarak halka hizmeti temel görev saydıklarını vurgulayan Birsel, bu hislerle yeni yıl bütçesine kabul oyu vereceklerini açıkladı. ${ }^{133}$

\section{Oylama ve Peker'in Teşekkürü}

Birsel'in konuşmasını takiben oylamaya geçildi. 402 milletvekilinin oy kullandığ1 1947 yılı bütçe tasarısı oylamasında 48 ret 354 kabul oyu kullanıldı. Bütçe kabul edildikten sonra kürsüye gelen Başbakan Recep Peker teşekkür konuşması yaptı. DP muhalefetindeki ilk bütçe görüşmeleri olaylı başlamıştı. Görüşmelerin ilk günü ya-

130 Tutanak Dergisi, a.g.e., s.841-843.

131 Tutanak Dergisi, a.g.e., s.843-844

132 Tutanak Dergisi, a.g.e., s.845.

133 Tutanak Dergisi, a.g.e., s.846-847. 
şanan olayın etkisinde kaldığı anlaşılan Peker, konuşmasının başında muhalefete şu sözlerle zeytin dalı uzattı:

"Bu bütçeye iç inanı ile beyaz oy veren arkadaşların yanında inanmadıkları bir şeye kırmızı oy vermek gibi iç inanlarının ifadesini aksettiren muhalif parti arkadaşlar da vazifelerini yapmışlardır. Bu itibarla bütün Kamutaya, tümünüze birden samimî teşekkürlerimi arzederim. Bu cümlenin derhal arkasından ilâve etmeliyim ki, Hükümetiniz çalışırken sabit fikirlere, hodkâm duygulara saplanarak yalnı kendi hareketlerini beğenenlerin fikirlerine ve sözlerine itibar etmekle kalmayacak, bizim doğru bildiğimiz yolu yanlış sayarak eksik gördüklerini tamamlamak maksadını takibeden muhalif arkadaşların fikirlerinden de Devlet için hayırlı olanları bulunursa aynı dikkatle bunlara da yer vereceğiz." 134

Demokratik yaşamın gereği olarak anlaşma ve konuşmanın önemine işaret eden Peker, böylesi bir medeni hayatın kuruluşunda yaşanan güçlüklerin birlikte aşılacağı$\mathrm{n} 1$ belirtti. Muhalefeti kucaklayan bu sözlerinin ardından temkini de elden birakmadı. Önceki konuşmasında muhalefeti halkı kışkırtmakla itham eden Peker, kanunsuz hareketlerin kanun gücüyle bastırılarak düzenin sağlanacağını söylemişti. Teşekkür konuşmasını bu ifadeleri çağrıştıran şu sözlerle sonlandırdı: "Bütün haklarl ve hürriyetleriyle haklı ve hür bir millet olarak şeref, kudret ve varlık içinde yaşamanın değişmez şartı nizamlı bir Devlet olarak yaşamanın yolunu bulmaktır. Hükümetin kanunlara dayanarak bu şartları telif edip ikisini yanyana ve beraber yürütmek hususundaki azmi katiyen değişmiyen bir zihniyet olarak yerinde durmaktadır." 135

Peker'in konuşmasını Demokratlar da alkışlamış, Mecliste "bayram havası" esmişti. ${ }^{136}$ Cumhurbaşkanı'nın, 30 Aralık'ta Menderes'i köşke yemeğe çağırması bu havaya katkı sağlamıştı. ${ }^{137}$ Taraflar arasında "Psikopat Olayı" ile alevlenen ortam İnönü'nün girişimleri ve Peker' in muhalefeti kucaklayan konuşmasıyla yatışmış gözüktü. Fakat bu dostluk havası gerçeği yansıtmıyordu. 1946 yılının son beş ayı içinde iki kez Meclise katılmama konusunu gündemlerine alan Demokratlar, bu seçeneği göz ardı etmeyeceklerini 7-11 Ocak 1947 tarihlerinde gerçekleştirilen DP Birinci Büyük Kongresi'nde göstermişlerdi. Kongrede kabul edilen Ana Davalar Komisyonu'nun hazırladığı raporda Anayasa’ya aykırı kanunlar değiştirilmediği takdirde partinin sine-i millete döneceği ifade edildi. Parlamento boykotu boyunca teşkilatlarından tam destek gören Demokratlar, kongreden aldıkları güçle muhalefetlerini daha da sertleştirmiş, iktidar aynı sertlikte karşılık vermişti. Süreç Menderes'in lehine Peker'in aleyhine sonuçlara gebeydi. Sağduyudan uzak ölçüsüz konuşmalarla giderek

134 Tutanak Dergisi, a.g.e., s.847-848., Cumhuriyet, 31 Aralık 1946.

135 Tutanak Dergisi, a.g.e., s.848-849.

136 Toker, a.g.e., s.229.

137 Albayrak, a.g.e., s.99. 
artan gerilim İnönü'nün partiler üstü gayretinin bir başka örneği olan 12 Temmuz Beyannamesini yayınlamasıyla bir süreliğine azaldı. Çok partili dönemin ilk başbakanı Peker, İnönü'nün ve partisinin desteğini yitirince 9 Eylül 1947'de görevden çekildi. Sancılarla dolu çok partili hayata geçiş dönemi 14 Mayıs 1950'de muhalefetin zaferiyle sonuçlandi.

\section{Sonuç}

Türkiye, İkinci Dünya Savaşı sonrası döneme çok partili sistemi hayata geçirme arzusuyla başlamış, 1946-1950 yılları bu arzunun sancılarına sahne olmuştu. İktidar ve muhalefet birbirlerine karşı tutumlarını ayarlamakta zorlanınca siyasal krizler peşi sıra geldi. Bu krizlerden biri de 1947 yılı bütçesi görüşmelerinde patlak verdi.

DP muhalefetindeki bu ilk bütçe görüşmelerinde partisi adına Adnan Menderes konuştu. Menderes bütçede samimiyet ilkelerine uyulmadığını, devlet işlerinde tasarruf fikrinin hâkim kılınmadığını, tekrar edilegelen denk bütçe ve ödeme dengesi sözlerinin anlamını yitirdiğini ve borçların artma eğiliminin sürdüğünü vurguladı. Bütçenin genel durumu dışında parlamenter rejimlerde adet olduğu üzere hükümetin genel siyasetini de bahis konusu yaptı. Hükümetin yönetim anlayışını eleştirirken iğneleyici sözler kulland.

Tek parti dönemi bütçe görüşmelerinde hükümetlerin iktisadi ve mali anlayışlarına eleştiriler getirilmesi olağan karşılanıyordu. Ancak çok partili dönemin bu ilk bütçe görüşmesinde hükümetin bütün olarak hedefe konulması alışılmadık bir durumdu. Bu durum karşısında Menderes'e cevap vermek isteyen Başbakan Recep Peker hiç hesapta yokken kürsüye geldi. Anlaşılan Menderes, sözleri ve üslubuyla Peker'i çileden çıkarmıştı. Peker'in tenkitlere karşılık verirken kullandığı sözlere tepki gösteren Demokratlar Meclisi terk etti. Siyasi yazına "Psikopat Olayı" adıyla geçen bu krizle birlikte bütçe görüşmelerinin yerini parti çatışmaları, iktisadi konuların yerini rejim tartışmaları aldı. Muhalifler alınganlık göstermekle iktidar tahammülsüzlükle suçlaniyordu.

Ilımlı muhalefet sergilediği gerekçesiyle teşkilatlarından eleştiri alan DP'nin parlamento boykotu partililerden büyük destek gördü. Yoğun destek telgrafları DP'nin yurt genelinde kökleştiğini gösteriyordu. Meclisten tamamen çekilmeyi gündemlerine alan Demokrat liderler böylesi radikal bir karar almaya cesaret edemiyordu. DP'nin göz ardı edilemez bir güce eriştiğini anlayan iktidar kanadı ise çok partili sistemin geleceği bakımından boykotun uzamasından endişe ediyordu. Bu konjonktür arabuluculuk girişimlerine etki yaptı. Cumhurbaşkanı İsmet İnönü’nün “26 Aralık Tebliği” ve partiler üstü girişimlerinin katkısıyla Demokratlar dokuz gün sonra Meclise katılma kararı aldı. Böylece parti ve devlet başkanlığı görevlerinin birbirinden ayrı tutulması fikrinin önemi açıkça görüldü.

1947 yılı bütçe oylamasından önce DP adına yine Menderes kürsüye geldi. Uzun konuşması boyunca DP'lilerin Meclisi terk etmeleriyle sonuçlanan olayın aktörle- 
rinden Başbakan Peker hakkında bir eleştiride bulunmadı. Peker adını kullanmaktan dahi imtina eden Menderes, buna karşın Maliye Bakanı Halit Nazmi Keşmir'i dilinden düşürmedi. Bu durum Menderes ve Demokratların yeniden tansiyonu yükseltecek bir ortama yol açmama isteklerinden kaynaklanmış olsa gerektir. Aynı hassasiyet iktidar kanadı açısından da söz konusuydu. Bütçe kabul edildikten sonra kürsüye gelen Başbakan Peker muhalefeti kucaklayan bir teşekkür konuşması gerçekleştirdi.

DP muhalefetindeki ilk bütçe görüşmelerinde 1947 yılı bütçesi kadar İkinci Dünya Savaşı yıllarındaki iktisat politikaları ve "tek parti zihniyeti” de masaya yatırıldı. Görüşmelerde 7 Eylül Kararları ve etkileri taraflar arasındaki bir numaralı ihtilaf sebebiydi. Bunun dışında devletçilik uygulamaları, milli koruma kanunu, ithalat ve ihracata yönelik kısıtlamalar, bütçenin samimiyeti, enflasyon, bütçede tasarruf zihniyeti ve borçlar da tartışmalara yol açtı.

Görüşmeler örgütlü muhalefetin potansiyelini gözler önüne serdi. Oysa tek parti günleri bütçe görüşmeleri sadece birkaç milletvekilinin eleştiride bulunduğu, hükümeti denetlemesi için parti içinden oluşturulan Müstakil Grup mensuplarının genellikle işin özüne temas etmediği, üstelik eleştiri getiren milletvekillerinin de bütçeye kabul oyu kullandığı bir dönem olmuştu.

DP'li ilk bütçe görüşmeleri tek partili Meclis geleneğinin son bulduğunu gösterdi. Bununla birlikte DP'lilerin yer almadığı oturumlarda bazı CHP ve bağımsız milletvekillerinin bütçe eleştirileri dikkat çekti. Bazı iktidar partililer devletçilik uygulamalarına ve Köy Enstitülerine sert çıktı. Bakanların birçoğu bu oturumlarda imkânsızlıkları açıkça ortaya koydu. Bu durum tek parti döneminden kalma bir alışkanlıktı. Ancak bazı CHP'liler daha da ileri giderek Başbakan Peker'i, Demokratların Meclisi terk etmesinde rolü olmakla itham etmişti. Çok partili sistem içinde böylesi bir kriz ortamında partisinin milletvekilleri tarafından haksız bulunmak Başbakan açısından iyiye işaret değildi. Peker, tartışılan çıkışıyla çok partili sisteme geçiş gibi kritik evreye uygun bir Başbakan olmadığı şeklindeki kanaati kuvvetlendirdi. Görüşmelere damga vuran Menderes ise parti içindeki konumunu güçlendirdi.

Bütçe görüşmelerinin ilk günü yaşanan kriz çok partili döneme geçişi sekteye uğratacak etkiler doğurmuştu. Ancak partili Cumhurbaşkanı'nın arabuluculuk girişimleri onun gelecekte de partiler üstü bir kimlikle denge kuracağı kanısına yol açtı. 12 Temmuz Beyannamesi bu kanıyı doğrulayacaktı. Bu durum muhalefete güven aş1lamış, iktidar üzerindeki baskıyı arttırmıştı. 


\section{Kaynakça}

\section{Resmi Yayınlar}

T.B.M.M. Tutanak Dergisi, Dönem:VII, Cilt:20.

T.B.M.M. Tutanak Dergisi, Dönem:VIII, Cilt:3.

\section{Kitaplar}

Akın, Rıdvan, Türk Siyasâl Tarihi 1908-1920, İstanbul, XII Levha Yayınları, 2010.

Albayrak, Mustafa, Türk Siyasi Tarihinde Demokrat Parti (1946-1960), Ankara, Phoenix Yayınevi, 2004. Arar, İsmail, Hükümet Programları 1920-1965, İstanbul, Burçak Yayınevi, 1968.

Aydemir, Şevket Süreyya, İkinci Adam 1938-1950, C.II, 11. bs., İstanbul, Remzi Kitabevi, 2011.

Aydemir, Şevket Süreyya, Menderes'in Dramı? (1899-1960), 15.bs., İstanbul, Remzi Kitabevi, 2014.

Başar, Ahmet Hamdi, Ahmet Hamdi Başar'ın Hatıraları: "Yine Hayal Âleminde Uçuyorum...", C.II, Haz. Murat Koraltürk, İstanbul, İstanbul Bilgi Üniversitesi Yayınları, 2007.

Eroğul, Cem, Demokrat Parti Tarihi ve İdeolojisi, 3. bs., Ankara, İmge Kitabevi, 1998

Goloğlu, Mahmut, Türkiye Cumhuriyeti Tarihi-IV 1946-1950 Demokrasiye Geçiş, İstanbul, Türkiye İş Bankası Kültür Yayınları, 2013.

İnönü, İsmet, Defterler 1919-1973, Haz. Ahmet Demirel, İstanbul, Yap1 Kredi Yayınları, 2016.

Kepenek, Yakup, Nurhan Yentürk, Türkiye Ekonomisi, 19.bs., İstanbul, Remzi Kitabevi, 2007.

Koçak, Cemil, "Siyasal Tarih (1923-1950)", Yakınçağ Türkiye Tarihi 1908-1980, C.I, Haz. Sina Akşin, İstanbul, Milliyet Yayınları, [t.y.].

Tanyeli, Halit, Adnan Topsakaloğlu, İzahlı Demokrat Parti Kronolojisi 1945-1950, İstanbul, İstanbul Matbaas1, 1958.

Tezel, Yahya S., Cumhuriyet Döneminin İktisadi Tarihi, 5.bs., İstanbul, Tarih Vakfı Yurt Yayınları, 2002.

Toker, Metin, Tek Partiden Çok Partiye, İstanbul, Milliyet Yayınları, 1970.

Tunaya, Tarık Zafer, Türkiye’de Siyasi Partiler 1859-1952, 3.bs., İstanbul, Arba Yayınları, 1995.

Us, Asım, Hatıra Notları, Haz. İsmail Dervişoğlu, İstanbul, Kitabevi Yayınları, 2012.

\section{Makaleler}

Erim, Nihat, "Bütçe görüşmeleri devam ederken”, Ulus, 25 Aralık 1946.

Erim, Nihat, "Meclisi terketmek vazifeden kaçmaktır”, Ulus, 19 Aralık 1946.

Erim, Nihat, "Vazifeler tek taraflı değil karşılıklıdır”, Ulus, 22 Aralık 1946.

Erim, Nihat, "Ya bu deveyi gütmeli ya..." Ulus, 30 Aralık 1946.

Fenik, Mümtaz Faik, “D.Partinin elde ettiği kazanç”, Vatan, 29 Aralık 1946.

Fenik, Mümtaz Faik, “İki Parti Arasında Normal Çalışma Devri”, Vatan, 28 Aralık 1946.

Fenik, Mümtaz Faik, “Ticaret Bakanının çok yersiz sözleri”, Vatan, 30 Aralık 1946.

Karataş, Murat, “Cumhuriyet Halk Partisi'nin Siyasal İktidar Anlayışı (1946-1950)”, Uluslararası Sosyal Araştırmalar Dergisi, Cilt: 7, Sayı: 29, 2014, s.505-524.

Köprülü, Fuat, "Bir siyasî buhranın sonu”, Kuvvet, 27 Aralık 1946.

Köprülü, Fuat, “Karşılıklı İtimad”, Kuvvet, 29 Aralık 1946. 
Köprülü, Fuat, "Kuru Tehditlerden Vazgeçiniz”, Kuvvet, 20 Aralık 1946.

Nadi, Nadir, "Kriz Bitti”, Cumhuriyet, 28 Aralık 1946.

Nadi, Nadir, "Yeni Bütçe", Cumhuriyet, 3 Ekim 1946.

Sadak, Necmettin, "Büyük Şefin Büyük hareketi”, Akşam, 28 Aralık 1946.

Sadak, Necmettin, "Bir Demokrat partili düşüncesile dahi..”, Akşam, 22 Aralık 1946.

Sadak, Necmettin, "Demokrat partisindeki kararsızlık ne gibi düşünceler uyandırıyor”, Akşam, 24 Aralık 1946.

Sadak, Necmettin, "Samimi olmak ve bütün neticelere önceden katlanmış olmak", Akşam, 29 Aralık 1946.

Tuna, Serkan, "Cumhuriyet Döneminin İlk Devalüasyonu 7 Eylül 1946," Akdeniz İ̈BF Dergisi, Cilt:7, Sayı:13, Mayıs 2007, s.86-121.

Yalman, Ahmet Emin, "Bütçe müzakeresinden umumî ilhamlar", Vatan, 19 Aralık 1946.

Yalman, Ahmet Emin, "Vaziyet tam manasiyla berraklaşmağa muhtaç", Vatan, 24 Aralık 1946. 